\title{
ע Omaishoitajien kokema kuormittuneisuus ja kaltoinkohtelu
}

Tutkimuksessa kuvataan omaishoitajien kuormittuneisuutta ja heidän kokemaansa kaltoinkohtelua hoidettavan taholta, sekä näiden tekijöiden välistä yhteyttä. Tutkimusaineisto kerättiin kyselylomakkeella viiden omaishoitoyhdistyksen niiltä jäseniltä, jotka olivat toimineet omaishoitajana vähintään 18 vuotta täyttäneelle hoidettavalle. Vastausprosentti oli 53,7\% $(\mathrm{N}=316)$.

Omaishoitajat olivat melko kuormittuneita, ja eniten heillä esiintyi ajallista, fyysistä ja itsensä kehittämisen kuormittuneisuutta. Näitä vähemmän heillä oli sosiaalista ja emotionaalista kuormittuneisuutta. Myös omaishoitajiin kohdistunut kaltoinkohtelu hoidettavan taholta oli yleistä, ja erityisesti omaishoitajat kokivat henkistä väkivaltaa ja henkilökohtaisten oikeuksien loukkaamista. Lisäksi moneen kohdistui sosiaalista kaltoinkohtelua ja fyysistä väkivaltaa. Vähiten omaishoitajat kokivat seksuaalista väkivaltaa, hengellistä kaltoinkohtelua ja taloudellista hyväksikäyttöä. Omaishoitajien kuormittuneisuuteen olivat yleisimmin yhteydessä omaishoitajien terveydentila ja taloudellinen tilanne, hoidettavan muistisairaus, käytösoireet ja päivittäinen avuntarve, hoitamiseen kulunut aika, hoitamisen fyysinen ja henkinen raskaus sekä omaishoitajïn kohdistuneet vaatimukset perheeltä, ystäviltä ja muilta henkilöiltä.

Omaishoitajien kokemaan kaltoinkohteluun olivat yhteydessä varsinkin asuminen yhdessä hoidettavan kanssa, oman puolison tai elämänkumppanin hoitaminen, hoidettavan muistisairaus, masennus ja käytösoireet, omaishoitajien taloudellisen tilanteen heikentyminen ja omaishoitajïn kohdistuneet vaatimukset muiden taholta. Omaishoitajien kokemalla kaltoinkohtelulla oli yhteys heidän kuormittuneisuuteensa. Mitä enemmän he kokivat kaltoinkohtelua, sitä kuormittuneempia he olivat. Kaltoinkohtelu aiheutti omaishoitajille etenkin emotionaalista, mutta myös fyysistä, sosiaalista ja itsensä kehittämisen kuormittuneisuutta.

\section{ASIASANAT: omaishoitaja, hoidettava, hoitosuhde, kuormittuneisuus, kaltoinkohtelu \\ MERVI LATOMÄKI, EILA RUNSALA, ANNA-MAIJA KOIVISTO, JARI KYLMÄ, EIJA PAAVILAINEN}

\section{YDINASIAT}

- Omaishoitajien kuormittuneisuutta, heidän hoidettavan taholta kokemaansa kaltoinkohtelua ja näiden ilmiöiden välistä yhteyttä on tutkittu vain vähän.

- Omaishoitajat kokevat varsinkin ajallista, fyysistä ja itsensä kehittämisen kuormittuneisuutta.

- Omaishoitajat kokevat kaltoinkohtelua hoidettavan taholta, erityisesti he kokevat henkistä väkivaltaa ja henkilökohtaisten oikeuksien loukkaamista.

- Omaishoitajien kokemalla kaltoinkohtelulla on yhteys heidän kuormittuneisuuteensa.

- Tutkimustuloksia voidaan hyödyntää kehitettäessä erilaisia palveluita ja tukimuotoja omaishoitajille sekä kehitettäessä arviointimenetelmiä kuormittuneiden ja kaltoinkohdeltujen omaishoitajien tunnistamiseksi. 


\section{JOHDANTO}

Omaishoitajuudella on tärkeä merkitys yhteiskunnassamme. Arviolta noin miljoona suomalaista hoitaa tai auttaa tällä hetkellä omaistaan tai läheistään, jolla on heikentynyt toimintakyky, vamma tai sairaus (1). Tilastoennusteiden mukaan vanhemmat ikäluokat (yli 85 -vuotiaat) kasvavat voimakkaasti, mikä ennakoi palvelutarpeen ja myös kustannusten kasvua. Tähän nykyisenkaltainen raskaampia palveluita korostava palvelujärjestelmä ei taloudellisista eikä laadullisista syistä pysty vastaamaan (2). Tutkimusten mukaan omais- ja läheisavulla on mahdollista merkittävästi vähentää yhteiskunnalle aiheutuvia kustannuksia. Ilman omais- ja läheisapua vuosittaiset sosiaali- ja terveydenhuollon kustannukset olisivat tällä hetkellä jopa 2,8 miljardia euroa nykyistä korkeammat. (3.)

Omaishoitamiseen liittyy sekä myönteisiä että kielteisiä kokemuksia. Toljamon ym. (4) mukaan useimmat omaishoitajat kokevat hoitamisen hyödylliseksi, heidän suhteensa hoidettavaan on hyvä, he arvostavat itseään omaishoitajana ja kokevat selviävänsä tehtävästään hyvin. Useissa tutkimuksissa (5-8) omaishoitajien on todettu kokevan myös kielteisiä tunteita, kuten menetyksen tunnetta, syyllisyyttä, vihaa, pelkoa, häpeää ja ahdistusta. Toisinaan omaishoitajuuteen saattaa liittyä jopa väkivaltaa omaishoitajaa kohtaan (9-10). Nämä kielteiset omaishoitokokemukset voivat kuormittaa omaishoitajia liikaa, jolloin he saattavat uupua tai sairastua.

Omaishoitajien kuormittuneisuuden ja kaltoinkohdelluksi joutumisen tunnistaminen ja ymmärtäminen auttavat suunnittelemaan ja tarjoamaan kullekin omaishoitajalle hänen tarpeisiinsa sopivat tukimuodot. Estämällä omaishoitajia uupumasta ja huolehtimalla heidän hyvinvoinnistaan mahdollistetaan omaishoidon toteutuminen turvallisena ja hoidettavan tarpeiden mukaisena. Näin omaishoito voi jatkua laadukkaana, ja hoidettavan muiden palveluiden tarve voi estyä tai siirtyä.

Tässä tutkimuksessa omaishoidolla tarkoitetaan paitsi virallista, toimeksiantosopimussuhteista omaishoitoa myös epävirallista, perheenjäseniltä, ystäviltä tai läheisiltä saatua apua, huolenpitoa tai hoivaa. Omaishoitaja voi olla hoidettavan avo- tai aviopuoliso, muu elämänkumppani, lapsi, vanhempi, miniä, vävy, anoppi, appi, muu sukulainen, ystävä, naapuri tai tuttava, joka an- taa joko virallista tai epävirallista apua, huolenpitoa tai hoivaa hänelle. Hoitoa, hoivaa tai apua saavasta vanhuksesta, sairaasta tai vammaisesta henkilöstä käytetään käsitettä hoidettava. (1112.) Vammaisuus käsittää kehitysvammaisuuden, erilaisia vammaa aiheuttavia sairauksia sekä tapaturman tai aivotapahtuman jälkitiloja.

Hoitosuhteella tarkoitetaan omaishoitoon liittyvää suhdetta, joka syntyy useimmiten jo olemassa olevaan ihmissuhteeseen, kuten pari-, vanhempi-lapsi- tai ystävyyssuhteeseen. Hoitosuhteeseen liittyy hoidettavan auttamista tai hoitamista, joka edellyttää ajallisten, taloudellisten, fyysisten ja henkisten voimavarojen olemassaoloa ja käyttöä. Hoitosuhteen kesto vaihtelee, pisimmillään se voi kestää hoidettavan koko eliniän. (2.)

Tässä tutkimuksessa kuormittuneisuus tarkoittaa omaishoitajien subjektiivista kokemusta fyysisestä, emotionaalisesta, sosiaalisesta, ajallisesta tai itsensä kehittämisen kuormittavuudesta (13). Kaltoinkohtelu tarkoittaa omaishoitajiin kohdistuvaa fyysistä, henkistä ja seksuaalista väkivaltaa, taloudellista hyväksikäyttöä, sosiaalista ja hengellistä kaltoinkohtelua sekä henkilökohtaisten oikeuksien loukkaamista (14-15). Kaltoinkohtelijana on omaishoitajan hoidettava.

Tutkimuksen tarkoituksena on kuvata omaishoitajien kuormittuneisuutta ja heidän kokemaansa kaltoinkohtelua hoidettavan taholta, sekä selvittää, millainen yhteys on omaishoitajien kuormittuneisuuden ja heidän kokemansa kaltoinkohtelun välillä. Tutkimuksella tuotetaan uutta tutkimustietoa, joka lisää sosiaali- ja terveydenhuollon ammattilaisten ja omaishoitajien läheisten ymmärrystä omaishoitajien arjesta. Saadulla tiedolla sekä ammattilaiset että läheiset pystyvät paremmin tunnistamaan avuntarpeessa olevat omaishoitajat ja voivat löytää keinoja heidän auttamisekseen. Lisäksi omaishoitoyhdistykset voivat hyödyntää tutkimuksen tuloksia toimintansa kehittämisessä yhdistystensä jäsenten hyväksi.

Tutkimuskysymykset ovat:

1. Millaista kuormittuneisuutta omaishoitajat kokevat?

2. Millaista kaltoinkohtelua omaishoitajat kokevat hoidettavan taholta?

3. Millainen yhteys omaishoitajaa, hoidettavaa ja hoitosuhdetta koskevilla taustatekijöillä on omaishoitajien kuormittuneisuuteen ja heidän kokemaansa kaltoinkohteluun? 
4. Millainen yhteys on omaishoitajien kuormittuneisuuden ja heidän kokemansa kaltoinkohtelun välillä?

\section{KUORMITTUNEISUUS JA KALTOINKOHTELU KIRJALLISUUDESSA}

Tutkimuksen teoreettiset lähtökohdat perustuvat kirjallisuushakuun, joka kohdistui Arto-, Medic-, Cinahl-, Medline-, PsycInfo-, Social Services Abstracts-, Assia-, Joanna Briggs- ja Cochrane Data-base of Systematic Reviews -tietokantoihin. Haut tehtiin asiasana- ja vapaasanahakuina seuraavilla hakusanoilla ja niiden eri yhdistelmillä: omaishoitaja, läheishoitaja, kaltoinkohtelu, väkivalta, kuormitus, caregiver, carer, maltreatment, mistreatment, abuse, violence, batter, "caregiver burden”, burden, stress ja strain. Tietokantahaut rajattiin suomen- ja englanninkielisiin, vuosina 2006-2016 julkaistuihin, vertaisarvioituihin tutkimusartikkeleihin. Tietoa haettiin myös manuaalisesti eri artikkeleista ja kirjallisuudesta. Lisäksi ennen tutkimuksen pohdintaosion kirjoittamista tehtiin uusi kirjallisuushaku edellä mainittuihin tietokantoihin rajaamalla haku vuosiin 20162017 ja haku päivitettiin artikkelin kirjoittamisvaiheessa. Tällä haluttiin varmistaa, että uusin tutkimustieto ilmiöstä on käytettävissä.

Suomessa omaishoitajien kuormittuneisuutta on tutkittu viimeisen kymmenen vuoden aikana verrattain vähän. Ilmiötä on tarkasteltu pääosin pro gradu -tutkielmissa ja muissa opinnäytetöissä, mutta siitä on tehty myös muutamia väitöskirjoja (16-18). Sen sijaan muista näkökulmista omaishoitajuudesta on tehty runsaasti tutkimusta Suomessakin (19-22).

Kansainvälisiä tutkimuksia omaishoitajien kuormittuneisuudesta on viimeisen kolmen vuoden aikana tehty lukuisia, tosin Pohjoismaista tutkimusta aiheesta on vähän. Muualta Euroopasta tutkimustietoa on saatavilla kohtalaisesti, eniten Espanjasta ja Italiasta. Yhdysvalloissa sekä Australiassa aihetta on tutkittu paljon, Aasiassa on tehty yksittäisiä tutkimuksia $(8,23-31)$.

Aikaisemman tutkimustiedon mukaan Suomessa omaishoitajista $31 \%$ on erittäin tai melko kuormittuneita ja $42 \%$ kohtalaisen kuormittuneita (4). Kansainvälisissä tutkimuksissa omaishoitajien vaikean tai keskivaikean kuormittuneisuuden esiintyvyys vaihtelee $12-50 \%$ :iin $(8,23-$ 31). Kansainvälisessä tutkimuskirjallisuudessa on tunnistettu useita omaishoitajaan, hoidettavaan ja hoitosuhteeseen liittyviä tekijöitä, jotka ovat yhteydessä omaishoitajien kuormittuneisuuteen. Etenkin naispuoliset (32-37), eronneet tai leskeytyneet $(34,38)$ omaishoitajat kokevat kuormittuneisuutta, ja varsinkin, jos heidän miespuolinen hoidettavansa käyttäytyy aggressiivisesti (35). Hoidettavan kanssa samassa taloudessa asuminen $(32,35,40)$, oman puolison, vanhemman $(34,36,37,41)$ tai lapsen hoitaminen $(42-43)$ ja perheen huono taloudellinen tilanne (32) kuormittavat omaishoitajia. Niin ikään omaishoitajien huono terveydentila $(37,44,45)$, alhainen koulutustaso $(32,38)$, sosiaalinen eristäytyneisyys (32), yksinäisyys $(25,31)$, sosiaalisen arvostuksen $(37,46)$ ja tuen puute $(36)$, omaishoitajien kokema roolivankeus $(47)$, roolikonflikti $(37,46)$, kielteiset kokemukset omaishoitamisesta (5) sekä naispuolisten omaishoitajien kokemus huonosta parisuhteesta ennen omaishoidon alkamista (39) lisäävät omaishoidon kuormittavuutta. Myös työskentely kodin ulkopuolella kuormittaa omaishoitajia $(34,46,47,48)$, tosin Garre-Olmon ym. (35) tutkimuksessa tulos oli päinvastainen. Omaishoitajien nuori ikä joko suojaa kuormittuneisuudelta (33-34) tai lisää sitä $(26,35,40)$.

Tutkimukset osoittavat, että omaishoitajien kuormittuneisuuteen ovat yhteydessä hoidettavan muistisairaus, kuten dementia ja Alzheimerin tauti $(22,36,44)$, sekä erityisesti muistisairailla esiintyneet käytösoireet $(35,49,50)$, esimerkiksi levottomuus (40,51), häiriökäyttäytyminen, aggressiivisuus $(39,46)$, ärtyneisyys $(40)$ ja disorientoitunut käyttäytyminen $(37,46)$. Niin ikään useat muut hoidettavan sairaudet, muun muassa Parkinsonin tauti (22), syöpä (52-53), depressio $(7,37,54)$, vammaisuus (25), aivohalvaus (55), mielenterveysongelma, päihderiippuvuus (56) ja monisairastavuus (57) aiheuttavat hoidontarvetta ja lisäävät omaishoitajien kuormittuneisuutta. Kuormittuneisuuteen on yhteydessä myös hoidettavan alentunut toimintakyky erilaisissa päivittäistoiminnoissa $(24,35,50)$ ja välineellisissä arkitoimissa $(37,49)$, kuten omien asioiden hoitamisessa (58). Lisäksi kuormittuneisuutta aiheuttavat hoidettavan jatkuva valvonnan tarve (36), mittava avuntarve $(32,46)$ ja suuri riippuvuus omaishoitajasta (35).

Hoitosuhteeseen liittyvistä tekijöistä varsinkin perheeltä tulevat vaatimukset lisäävät omaishoidon kuormittavuutta (59). Samoin omaishoidon on todettu olevan sitä kuormittavampaa, 
mitä kauemmin hoitosuhde on kestänyt $(38,54$, $60,61)$, ja mitä suurempi on omaishoitoon kuluva päivittäinen tuntimäärä $(32,48,54)$.

Omaishoitajien kokemaa kaltoinkohtelua hoidettavan taholta on tutkittu melko niukasti, eikä varsinkaan suomalaista tai pohjoismaista tutkimusta aiheesta ole olemassa. Aihetta on tutkittu lähinnä Yhdysvalloissa, Kanadassa, Taiwanissa ja Japanissa (10,62-68). Näissä kansainvälisissä tutkimuksissa kaltoinkohtelun esiintyvyys vaihtelee 29-53 \% (9,10,67,69,70). Fyysistä kaltoinkohtelua omaishoitajista on kokenut 6-35\% $(9,68,70,71)$, henkistä kaltoinkohtelua $25-36 \%$ $(9,63,68)$, sanallista kaltoinkohtelua $32-60 \%$ $(62,63,69)$, taloudellista hyväksikäyttöä $32 \%$ (71) ja seksuaalista väkivaltaa alle $1 \%(63,71)$. Useat omaishoitajaan, hoidettavaan ja hoitosuhteeseen liittyvät tekijät ovat yhteydessä omaishoitajien kokemaan kaltoinkohteluun hoidettavan taholta. Omaishoitajat, jotka asuvat hoidettavan kanssa samassa taloudessa $(64,68)$ tai hoitavat häntä yksin (67), kokevat muita omaishoitajia enemmän kaltoinkohtelua. Tyypillisesti kaltoinkohtelu kohdistuu omaishoitajiin, jotka ovat hoidettavan perheenjäseniä, ja erityisesti se kohdistuu vaimoon $(62,65)$ tai tyttäreen (62). Riskiä lisää myös parisuhde (72), hoidettavan miessukupuoli $(9,10,62,65,67,70)$, nuori $(67)$ tai vanha ikä $(10,68)$, hoidettavan yksin eläminen (67) ja hoidettavan aikaisempi väkivaltainen käyttäytyminen (10).

Hoidettavan sairauksista varsinkin skitsofrenia (68), psykoosi (67), dementia, käytösoireet (10), vammaisuus (72) sekä hoidettavan alentunut toimintakyky päivittäistoiminnoissa (9) ovat yhteydessä omaishoitajien kokemaan kaltoinkohteluun. Toisaalta myös toimintakyvyltään parempikuntoiset hoidettavat saattavat kaltoinkohdella omaishoitajaansa (69). Niin ikään ennen omaishoitosuhteen alkamista esiintynyt hoidettavan aggressiivinen käyttäytyminen on riskitekijä kaltoinkohtelulle (10). Taloudellisen kaltoinkohtelun riski lisääntyy, jos hoidettava on päihteiden väärinkäyttäjä tai mielenterveysongelmainen (73). Samoin päivittäinen hoitoaika (9), parisuhteessa aikaisemmin tapahtunut väkivalta $(10,74)$ ja perheen matalat tulot $(68,70)$ lisäävät omaishoitajien riskiä joutua kaltoinkohdelluksi.

Omaishoitajien kuormittuneisuuden ja heidän hoidettavan taholta kokemansa kaltoinkohtelun välistä yhteyttä ei ole tutkittu Suomessa lainkaan, ja kansainvälistäkin tutkimusta ilmiöstä on hyvin vähän $(10,59,64,67,68,75)$ Viimeisen viidentoista vuoden aikana sitä on tutkittu tiettävästi vain Tanskassa, Belgiassa, Turkissa, Japanissa, Yhdysvalloissa, Kanadassa ja Australiassa ja lähinnä tilanteessa, kun hoidettava on ikääntynyt tai hänellä on skitsofrenia, psykoosi tai muu psyykkinen sairaus, muistisairaus, vammaisuus tai kehitysvammaisuus $(5,10$, $63,64,67,68,71,75)$.

Tutkimuksissa omaishoitajien kuormittuneisuuden ja heidän kokemansa kaltoinkohtelun välillä todettiin yhteys, kun hoidettavalla oli skitsofreniaan liittyvää väkivaltaista käyttäytymistä, häirintää ja loukkaavaa kielenkäyttöä omaishoitajaa kohtaan tai hän käytöksellään esti omaishoitajaa nukkumasta $(64,75)$. Yhteys oli myös, kun muistisairas hoidettava oli aggressiivinen tai vammainen hoidettava käytti fyysistä tai sanallista väkivaltaa omaishoitajaa kohtaan $(10,63)$. Kaltoinkohtelua kokeneet omaishoitajat olivat kuormittuneita varsinkin, kun hoidettava oli iäkäs $(59,68,71)$, skitsofreniaa sairastavan henkilön omaishoitaja oli hoidettavan vanhempi, perheen tulot olivat matalat, perhe koki suurta stigmaa hoidettavan sairauden takia (68) tai hoitaminen oli negatiivinen kokemus omaishoitajalle (5).

\section{MENETELMÄT}

\section{AINEISTO}

Tutkimusaineisto kerättiin kyselylomakkeilla viiden Suomessa toimivan omaishoitoyhdistyksen jäseniltä $(\mathrm{n}=589)$ maaliskuussa 2017. Tutkimuksen kohderyhmänä olivat jäsenet, jotka toimivat parhaillaan tai ovat aiemmin toimineet omaishoitajana aikuiselle eli vähintään 18 vuotta täyttäneelle hoidettavalle. Hyväksyttyjä kyselylomakkeita palautui 316 , ja vastausprosentti oli 53,7 \%.

\section{MITTARIT}

Tutkimusta varten laadittu kyselylomake sisälsi omaishoitajaa, hoidettavaa ja hoitosuhdetta koskevia taustatietokysymyksiä sekä omaishoitajan kokemaa kuormittuneisuutta ja kaltoinkohtelua mittaavia kysymyksiä. Omaishoitajan taustatietoina kysyttiin syntymävuotta, sukupuolta, siviilisäätyä, korkeinta koulutusta, terveydentilaa, taloudellista tilannetta, asumista suhteessa 
hoidettavaan, työssäoloa ja työelämästä poisjättäytymistä hoitamisen vuoksi. Hoidettavan taustatietoina kysyttiin syntymävuotta, sukupuolta, suhdetta omaishoitajaan, pääasiallisinta hoitamisen syytä, käytösoireita sekä avuntarvetta päivittäistoiminnoissa ja välineellisissä arkitoimissa. Hoitosuhteesta kysyttiin kestoa, hoitamisen useutta, hoitamiseen käytettyä aikaa, avuntarvetta tunteina päivässä sekä omaishoitajaan kohdistuvia, perheen, ystävien tai ulkopuolisten henkilöiden esittämiä vaatimuksia. Lisäksi kysyttiin omaishoitamisesta johtuvaa taloudellisen tilanteen heikentymistä sekä omaishoitajan arviota asteikolla 0-10, miten fyysisesti ja henkisesti raskaaksi hän kokee hoidettavan hoitamisen (1=ei lainkaan raskasta, 10=erittäin raskasta).

Omaishoitajan kuormittuneisuutta mitattiin Caregiver Burden Inventory (CBI) -mittarilla (13), joka sisältää 24 viisiportaista Likert-asteikollista väittämää (1=ei koskaan, 2=harvoin, $3=$ joskus, 4=aika usein, 5=melkein aina). Väittämistä muodostui viisi omaishoitajan kuormittuneisuutta mittaavaa ulottuvuutta: ajallinen kuormittavuus (5 väittämää), itsensä kehittämisen kuormittavuus (5 väittämää), fyysinen kuormittavuus (4 väittämää), sosiaalinen kuormittavuus (5 väittämää) ja emotionaalinen kuormittavuus (5 väittämää). Omaishoitajan ajallista kuormittuneisuutta mittaavat väittämät tarkastelevat omaishoidon aiheuttamia rajoituksia omaishoitajan ajankäyttöön. Itsensä kehittämisen kuormittuneisuutta mittaavat väittämät kuvaavat omaishoitajan kokemusta siitä, että elämä ei menekään normaalin elämänkulun mukaisesti saman ikäisiin verrattuna. Fyysistä kuormittuneisuutta mittaavat väittämät koskevat omaishoitajan fyysistä terveydentilaa, väsymistä ja nukkumista. Sosiaalista kuormittuneisuutta mittaavilla väittämillä arvioidaan omaishoitajan kokemusta roolikonfliktista. Emotionaalista kuormittuneisuutta koskevilla väittämillä mitataan kielteisiä tunteita, joita omaishoitaja saattaa tuntea hoidettavaa kohtaan, mikä aiheuttaa hänelle kuormittavaa syyllisyyttä. (13.) Yhteyksien tarkastelemiseksi väittämistä muodostettiin kuusi summamuuttujaa: kokonaiskuormittuneisuus, ajallinen, itsensä kehittämisen, fyysinen, sosiaalinen ja emotionaalinen kuormittuneisuus. (Taulukko 2.)

Omaishoitajan kokeman kaltoinkohtelun mittaamiseen käytettiin AVOW-tutkimuksen (76) kyselylomakkeesta taloudellista hyväksikäyttöä, henkistä, fyysistä ja seksuaalista väkivaltaa sekä henkilökohtaisten oikeuksien loukkaamista koskevat kysymykset. Teoreettisen lähtökohtien perusteella mittariin lisättiin sosiaalista ja hengellistä kaltoinkohtelua mittaavat kysymykset. Mittarista muodostui viisiportainen (1=ei koskaan, $2=$ harvemmin kuin kuukausittain, 3=kuukausittain, 4=viikoittain, 5=päivittäin tai lähes päivittäin) ja se sisälsi 31 väittämää.

Omaishoitajan kokeman kaltoinkohtelun eri ulottuvuuksia kuvaavien summamuuttujien muodostamiseksi kaltoinkohtelumittarin rakennevaliditeettia tutkittiin alustavasti eksploratiivisella eli aineistolähtöisellä faktorianalyysillä. Ekstraktiomenetelmäksi valittiin Generalized Least Squares -menetelmä, ja faktoreiden rotaatio tehtiin vinokulmarotaatiomenetelmällä. Aineiston soveltuvuutta faktorianalyysiin testattiin Bartlettin sfäärisyystestillä ( $<<0,001)$, Kaiser-MeyerOlkin testillä (KMO 0,816), väittämien kommunaliteeteillä $(>0,30)$ sekä väittämien ja faktoreiden välisillä latauksilla $(>0,40)$ (77). Aineisto todettiin faktorianalyysiin soveltuvaksi. Faktorianalyysin tuloksena ekstraktoitui yhdeksän faktoria. Mittarin kaksi muuttujaa ("Kuinka usein hoidettavanne tai avustettavanne on ... vähätellyt sitä, mitä teette?" ja "Kuinka usein hoidettavanne tai avustettavanne on ... puhunut Teille siveettömästi niin, että olette tuntenut olonne epämukavaksi?”) eivät latautuneet edellä mainituille faktoreille, joten ne jätettiin pois summamuuttujia muodostettaessa.

Summamuuttujien muodostamisessa hyödynnettiin sekä faktorianalyysin antamaa alustavaa tietoa tutkittavasta ilmiöistä että ilmiötä kuvaavaa teoreettista tietoa. Sisällöllisesti mielekkään tulkinnan aikaansaamiseksi faktoreiden pohjalta tehtiin seitsemän summamuuttujaa, jotka kuvaavat omaishoitajan kokeman kaltoinkohtelun eri ulottuvuuksia: fyysinen väkivalta (5 väittämää), henkinen väkivalta (4 väittämää), taloudellinen hyväksikäyttö (3 väittämää), henkilökohtaisten oikeuksien loukkaaminen (7 väittämää), seksuaalinen väkivalta (2 väittämää), sosiaalinen kaltoinkohtelu (4 väittämää) ja hengellinen kaltoinkohtelu (4 väittämää) (Taulukko 3.).

Fyysinen väkivalta tarkoitti hoidettavan omaishoitajaan kohdistamaa uhkailua ja fyysisen koskemattomuuden loukkaamista, henkinen väkivalta hoidettavan omaishoitajaan kohdistamaa sanallista aggressiivista käyttäytymistä sekä 
omaisuuden tuhoamista, ja taloudellinen hyväksikäyttö omaishoitajaan kohdistuvaa rahan tai omaisuuden kiristämistä, varastamista tai taloudellisen hyödyn tavoittelua. Henkilökohtaisten oikeuksien loukkaaminen koski kaltoinkohtelua, joka liittyi omaishoitajan henkilökohtaisen vapauden ja itsemääräämisoikeuden toteutumiseen, seksuaalinen väkivalta tarkoitti hoidettavan omaishoitajaan kohdistamaa seksuaalista painostamista tai hyväksikäyttöä, sosiaalinen kaltoinkohtelu hoidettavan aiheuttamaa omaishoitajan sosiaalista eristämistä tai leimaantumista ja hengellinen kaltoinkohtelu rajoituksia omaishoitajien uskonnonvapauteen ja oikeuteen toteuttaa hengellisiä tarpeitaan. Kaltoinkohtelumittarin 31 väittämästä muodostettiin myös yksi omaishoitajan kokemaa kokonaiskaltoinkohtelua kuvaavaa summamuuttuja. Lisäksi kaikista summamuuttujista muodostettiin dikotomiset muuttujat $(0=$ ei ole kokenut kaltoinkohtelua, $1=$ on kokenut kaltoinkohtelua), jolloin saatiin käsitys, kuinka moni vastaajista yleensä ottaen oli kokenut kaltoinkohtelua.

\section{TILASTOLLISET ANALYYSIT}

Aineisto analysoitiin SPSS Statistics 24.0 -tilastoohjelmalla. Muuttujien jakaumien normaalisuudet tarkistettiin keskiarvoilla, mediaaneilla, histogrammeilla, jakauman vinoutta ja huipukkuutta kuvaavilla skewness- ja kurtosis -luvuilla sekä Kolmogorov-Smirnovin testillä. Aineiston kuvailussa käytettiin keski- ja hajontalukuja sekä frekvenssejä ja prosenttilukuja. Jatkuvien muuttujien välistä yhteyttä testattiin normaalisti jakautuneissa muuttujissa Pearsonin korrelaatiokertoimella ja vinosti jakautuneissa Spearmanin järjestyskorrelaatiokertoimella. Korrelaatiokertoimen arvoa tulkittiin siten, että itseisarvot alle 0,3 tarkoittavat heikkoa, arvot 0,3-0,49 kohtalaista ja arvot 0,5 tai yli voimakasta korrelaatiota (77). Luokittelevien muuttujien ja normaalisti jakautuneiden jatkuvien muuttujien välistä yhteyttä tarkasteltiin T-testillä ja varianssianalyysillä, jonka parivertailussa käytettiin Bonferronia. Luokittelevien muuttujien ja vinosti jakautuneiden jatkuvien muuttujien välisen yhteyden tarkastelussa käytettiin Mann-Whitney U - ja Kruskall-Wallis H -testejä. Jos epäparametrisissä testeissä ei keski- ja hajontaluvuilla saatu esiin ryhmien välisiä eroja, käytettiin havaintojen järjestyslukujen keskiarvoja (Mean Rank). Tällöin suurempi keskiarvo kuvasti sitä, että alkuperäiset havainnot olivat kyseisessä ryhmässä keskimäärin muita ryhmiä suuremmat. Summamuuttujien sisäistä johdonmukaisuutta arvioitiin Cronbachin alfa -kertoimella, jonka hyväksyttävänä arvona pidettiin $>0,70$. Tilastollisen merkitsevyyden rajana tutkimuksessa pidettiin p:n arvoa <0,05. (77.) Muuttujien välisistä yhteyksistä on raportoitu ainoastaan tilastollisesti merkitsevät.

\section{TULOKSET}

\section{TAUSTATEKIJÄT}

Omaishoitajat olivat 38-93 vuotiaita ja heidän keski-ikänsä oli 72 (38-93) vuotta. Enemmistö heistä oli naisia, ja oli hoidettavan kanssa parisuhteessa. Noin kolmasosa oli suorittanut peruskoulun, keskikoulun, kansakoulun, kansalaiskoulun tai ammatillisen perustutkinnon. Suurin osa koki terveydentilansa ja taloudellisen tilanteensa hyväksi, melko hyväksi tai kohtalaiseksi. Pääsääntöisesti omaishoitajat asuivat hoidettavan kanssa samassa taloudessa, eivät tehneet muuta työtä omaishoitamisen ohella eivätkä jättäytyneet hoitamisen takia pois työelämästä. Hoidettavat olivat syntyneet vuosina 1912-1998 (Md=1938;Q1=1930;Q3=1947), enemmistö heistä oli miehiä ja omaishoitajan puolisoita tai elämänkumppaneita. Yleisimpiä hoitamisen syitä olivat muistisairaus, vanhuuteen liittyvä toimintakyvyn heikkeneminen, vammaisuus, aivohalvaus ja masennus. Lähes puolet hoidettavista oli monisairaita, heillä oli vähintään kaksi sairautta syynä hoidon tarpeeseen. Suurimmalla osalla hoidettavista oli käytösoireita, eniten ärtyneisyyttä, levottomuutta, harhaisuutta, aggressiivisuutta tai vääristynyt vuorokausirytmi. Joka kymmenenteen omaishoitajaan kohdistui usein vaatimuksia perheeltä, ystäviltä tai ulkopuolisilta henkilöiltä. Lisäksi osalla omaishoitajista taloudellinen tilanne oli heikentynyt hoitamisen takia (Taulukko 1.). Hoidettavien avuntarve päivittäistoiminnoissa (ADL) $(\mathrm{Md}=2,2 ; \mathrm{Q} 1=1,8 ; \mathrm{Q} 3=3,0)$ oli vähäisempää kuin välineellisissä arkitoimissa (IADL) $(\mathrm{Md}=3,6$;$\mathrm{Q} 1=3,0 ; \mathrm{Q} 3=4,0)$. Päivittäistoiminnoissaan hoidettavat tarvitsivat eniten apua peseytymisessä, pukeutumisessa ja WC-käynneissä, vähiten syömisessä. Välineellisissä arkitoimissa avuntarve oli suurinta kodinhoitotehtävissä, ostosten teossa, raha-asioiden hoidossa ja ruoanvalmistuksessa, 


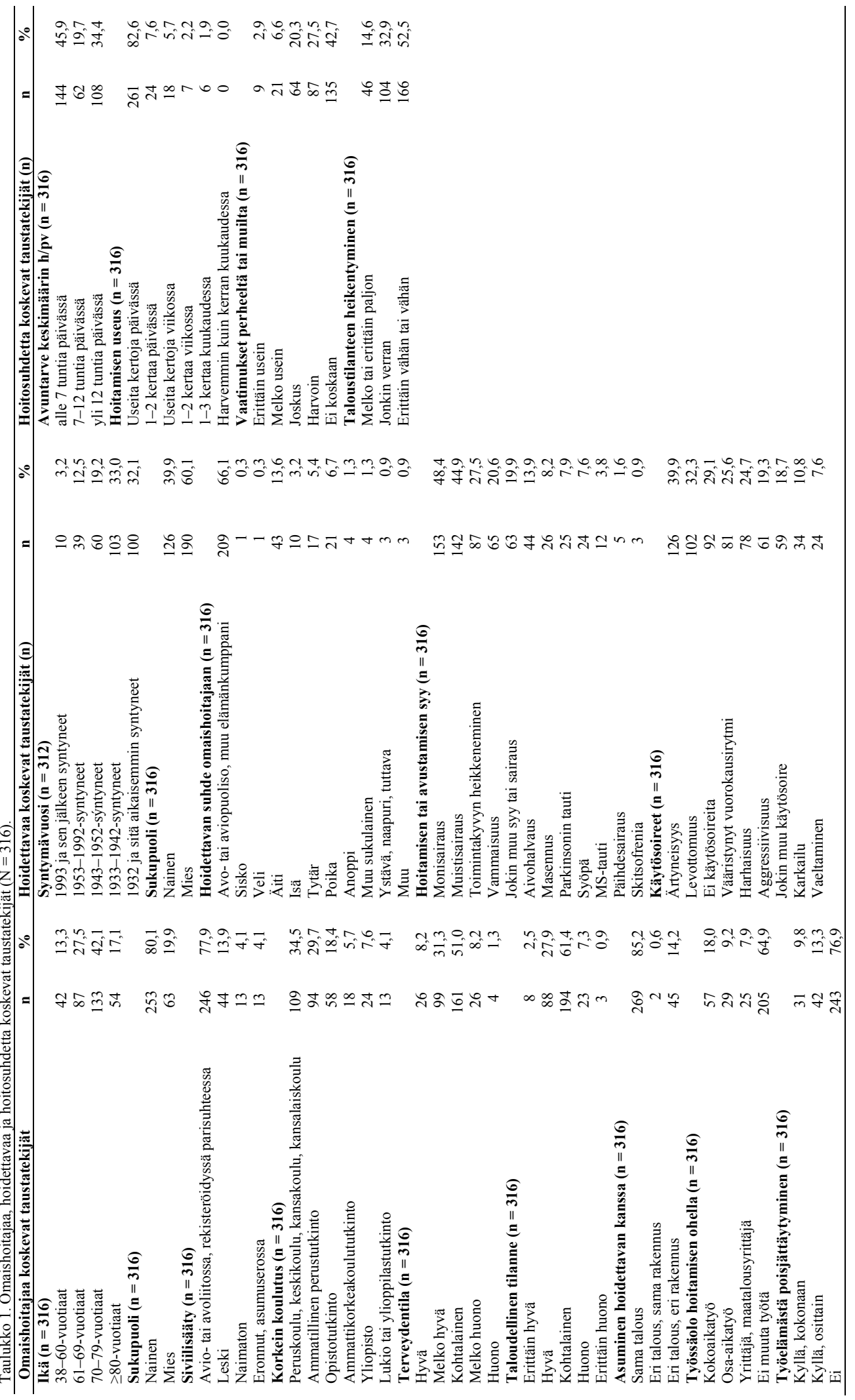


vähäisintä puhelimen käytössä. Omaishoitosuhde oli kestänyt keskimäärin 7,2 vuotta (5 kk-57 v), hoitamiseen käytettiin keskimäärin 8 tuntia päivässä ja suurin osa hoidettavista tarvitsi apua useita kertoja päivässä, neljäsosa (25,6 \%) ympärivuorokautisesti. Asteikolla 1-10 arvioituna omaishoitajat kokivat hoitamisen enemmän henkisesti $(\mathrm{Md}=7,0 ; \mathrm{Q} 1=6,0 ; \mathrm{Q} 3=8,0)$ kuin fyysisesti $(\mathrm{Ka}=6,1, \mathrm{Kh}=2,3)$ raskaaksi.

\section{OMAISHOITAJIEN KUORMITTUNEISUUS}

Omaishoitajat olivat keskimäärin melko kuormittuneita. Eniten he kokivat ajallista, mutta paljon myös fyysistä ja itsensä kehittämisen kuormittuneisuutta. Vähemmän he toivat esiin sosiaalista ja emotionaalista kuormittuneisuutta. (Taulukko 2.)

Tutkimuksen taustatekijöistä omaishoitajien kokonaiskuormittuneisuuteen olivat yhteydessä omaishoitajien huono terveydentila, huono taloudellinen tilanne ja sen heikentyminen, puolison hoitaminen, hoidettavan muistisairaus, MStauti ja käytösoireet. Yhteydessä olivat myös hoitamisen suuri fyysinen $(r=0,525)$ ja henkinen $(\mathrm{r}=0,655)$ raskaus, hoitaminen useita kertoja tai useita tunteja $(r=0,340)$ päivässä sekä omaishoitajiin kohdistuneet vaatimukset muiden taholta. (Liitetaulukot 1-2.)

Ajalliseen kuormittuneisuuteen olivat yhteydessä omaishoitajan huono terveydentila, huono tai heikentynyt taloudellinen tilanne, asuminen hoidettavan kanssa, hoidettavan muistisairaus, heikentynyt toimintakyy, Parkinsonin tauti ja käytösoireet. Ajallisesti kuormittuneita olivat myös omaishoitajat, jotka hoitivat useita kertoja tai useita tunteja päivässä $(r=0,608)$, eivät tehneet muuta työtä hoitamisen ohella, olivat jättäytyneet pois työelämästä tai kokivat hoitamisen fyysisesti $(r=0,595)$ tai henkisesti $(r=0,549)$ raskaaksi. (Liitetaulukot 1-2.)

Itsensä kehittämisen kuormittuneisuutta kokivat omaishoitajat, joiden terveydentila ja taloudellinen tilanne olivat huonoja, joiden taloudellinen tilanne oli heikentynyt omaishoitosuhteen vuoksi, jotka olivat jättäytyneet pois työelämästä tai joiden hoidettavalla oli muistisairaus tai käytösoireita. Lisäksi sitä kokivat omaishoitajat, jotka hoitivat useita kertoja päivässä, kokivat hoitamisen fyysisesti $(r=0,439)$ tai henkisesti $(r=0,633)$ raskaaksi tai joihin kohdistui vaatimuksia muiden henkilöiden taholta. (Liitetaulukot 1-2.)
Fyysisesti kuormittuneita olivat omaishoitajat, joiden hoidettava oli mies, jotka hoitivat puolisoaan tai lastaan, joiden terveydentila tai taloudellinen tilanne olivat huonoja tai joiden taloudellinen tilanne oli heikentynyt hoitamisen vuoksi. Fyysiseen kuormittuneisuuteen olivat yhteydessä myös hoidettavan muistisairaus ja käytösoireet, hoitamisen suuri fyysinen $(r=0,550)$ ja henkinen $(r=0,558)$ raskaus, omaishoitajaan kohdistuneet vaatimukset muiden taholta sekä hoitaminen useita kertoja tai useita tunteja $(\mathrm{r}=0,363)$ päivässä. (Liitetaulukot 1-2.)

Sosiaalisesti kuormittuneita olivat erityisesti naimattomat ja 38-60-vuotiaat omaishoitajat, sekä omaishoitajat, joiden terveydentila tai taloudellinen tilanne olivat huonoja, joiden taloudellinen tilanne oli heikentynyt hoitamisen takia, jotka tekivät muuta työtä hoitamisen ohella tai joiden hoidettavalla oli käytösoireita. Kuormittuneita olivat myös omaishoitajat, jotka kokivat hoitamisen henkisesti raskaaksi $(r=0,336)$ ja joihin kohdistui vaatimuksia muiden taholta. (Liitetaulukot 1-2.)

Emotionaalista kuormittuneisuutta kokivat naispuoliset omaishoitajat, ja omaishoitajat, joiden hoidettava oli mies, joiden terveydentila oli huono tai joihin kohdistui vaatimuksia muiden taholta. Emotionaalista kuormittuneisuutta koettiin myös, jos hoitaminen oli fyysisesti $(r=0,147)$ tai henkisesti $(r=0,353)$ raskasta tai hoidettavalla oli muistisairaus, masennus tai käytösoireita. (Liitetaulukot 1-2.)

\section{OMAISHOITAJIEN KOKEMA KALTOINKOHTELU}

Suurin osa $(60,3 \%)$ tutkimukseen osallistuneista omaishoitajista oli kokenut kaltoinkohtelua hoidettavan taholta hoitosuhteen aikana. Eniten omaishoitajat olivat kokeneet henkistä väkivaltaa $(40,7 \%)$ ja henkilökohtaisten oikeuksien loukkaamista $(35,4 \%)$. Viidesosa oli kokenut sosiaalista kaltoinkohtelua $(20,0 \%)$ ja fyysistä väkivaltaa $(19,0 \%)$, vajaa kymmenesosa $(8,9 \%)$ seksuaalista väkivaltaa. Vähiten omaishoitajat olivat kokeneet hengellistä kaltoinkohtelua $(6,1 \%)$ ja taloudellista hyväksikäyttöä $(4,5 \%)$. (Taulukko 3.)

Kokonaiskaltoinkohteluun olivat yhteydessä omaishoitajan huono taloudellinen tilanne, sen heikentyminen hoitamisen takia, asuminen hoidettavan kanssa, puolison hoitaminen, hoidettavan muistisairaus, masennus ja käytösoireet sekä 


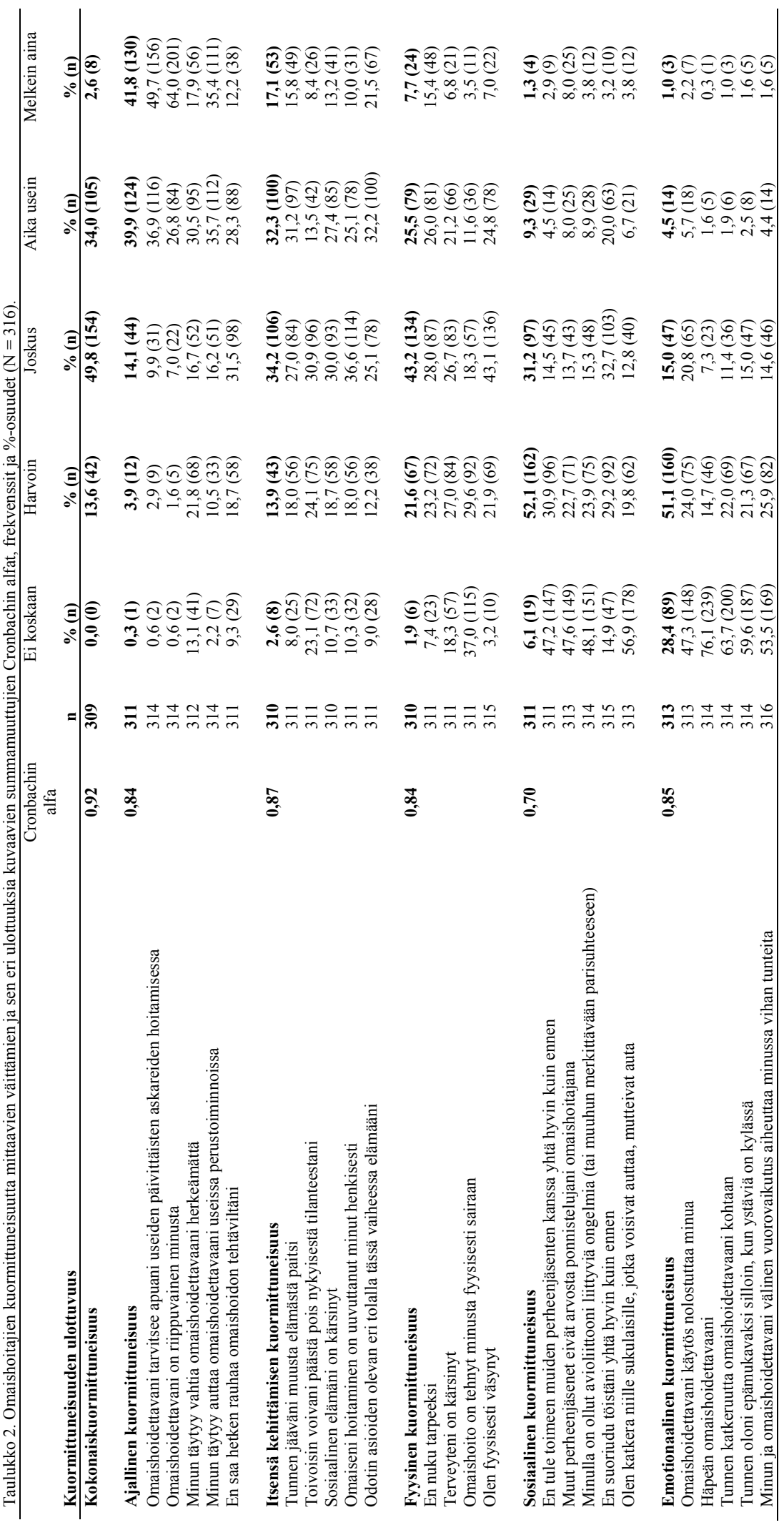




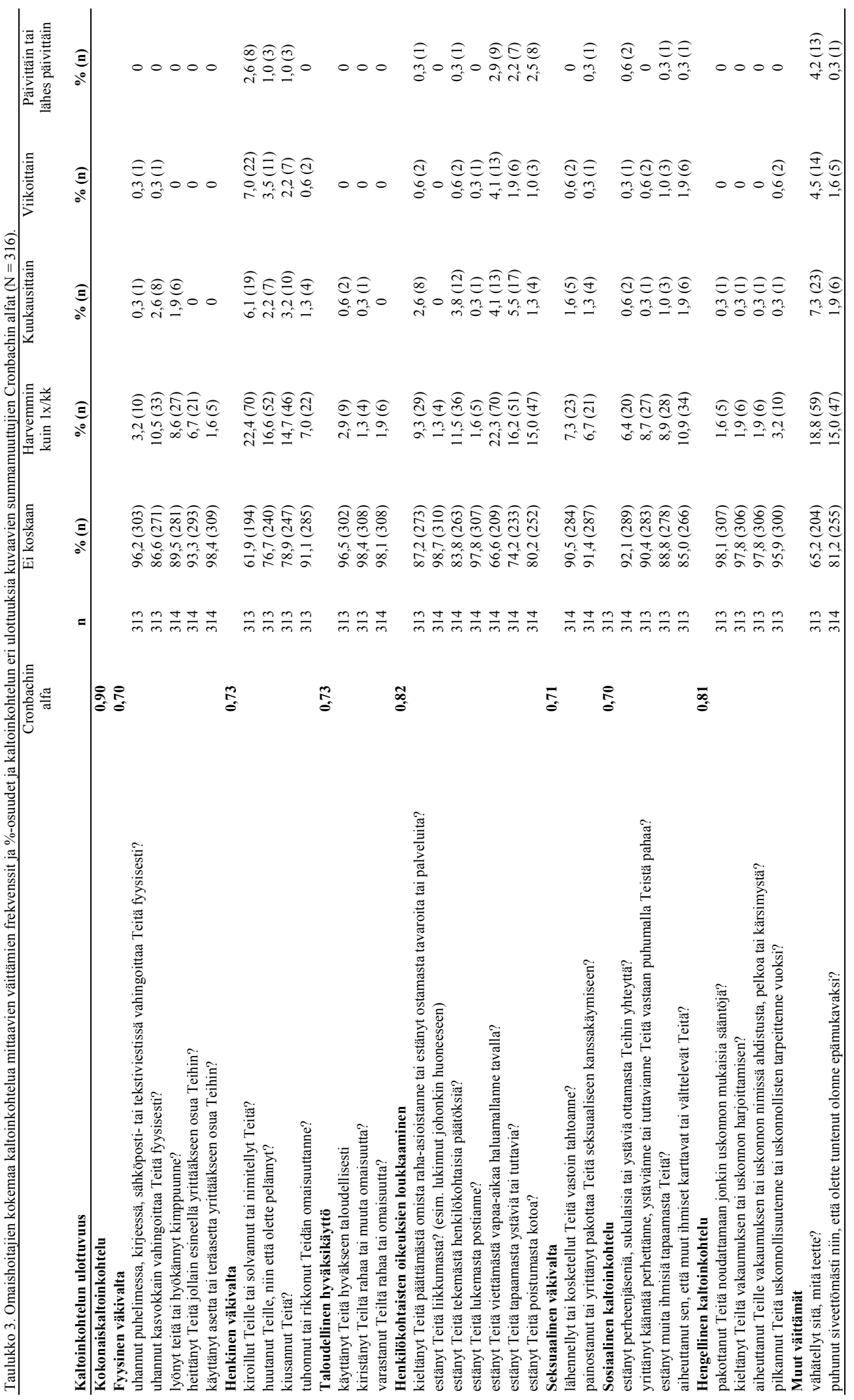


omaishoitajiin kohdistuneet vaatimukset muiden taholta. (Liitetaulukko 3.)

Henkiseen väkivaltaan yhteys oli omaishoitajien kohtalaisella terveydentilalla, hoidettavan kanssa samassa taloudessa asumisella, hoidettavan miessukupuolella, oman puolison hoitamisella, hoidettavan muistisairaudella, masennuksella ja käytösoireilla sekä omaishoitajiin kohdistuneilla vaatimuksilla. Seksuaalista kaltoinkohtelua kokivat erityisesti iäkkäämmät, hoidettavan kanssa yhdessä asuneet tai miestään hoitaneet omaishoitajat. Sitä koettiin myös, jos hoidettavalla oli muistisairaus, masennus tai käytösoireita. (Liitetaulukko 3.)

Henkilökohtaisten oikeuksien loukkaamista kokivat omaishoitajat, jotka hoitivat puolisoaan tai joiden hoidettavalla oli muistisairaus, masennus tai käytösoireita. Samoin sitä koettiin, kun omaishoitajan taloudellinen tilanne oli heikentynyt hoitamisen vuoksi, kun omaishoitaja koki vaatimuksia muiden taholta tai kun hän asui yhdessä hoidettavan kanssa. (Liitetaulukko 3.)

Fyysiseen väkivaltaan olivat yhteydessä hoidettavan masennus, käytösoireet ja omaishoitajiin kohdistuneet vaatimukset muiden taholta.
Omaishoitajien taloudelliseen hyväksikäyttöön olivat puolestaan yhteydessä hoidettavan skitsofrenia, ärtyneisyys, levottomuus, vääristynyt vuorokausirytmi sekä avuntarve useita kertoja viikossa. Hengellistä kaltoinkohtelua esiintyi, kun hoidettavalla oli Parkinsonin tauti tai käytösoireita tai kun omaishoitajaan kohdistui vaatimuksia muiden taholta. Sosiaalista kaltoinkohtelua kokivat omaishoitajat, joiden hoidettavalla oli muistisairaus tai käytösoireita, joiden taloudellinen tilanne oli heikentynyt tai jotka kokivat vaatimuksia muiden taholta. (Liitetaulukko 3.)

\section{KUORMITTUNEISUUDEN JA KALTOINKOHTELUN VÄLINEN YHTEYS}

Omaishoitajien kokonaiskuormittuneisuuden ja heidän hoidettavan taholta kokemansa kokonaiskaltoinkohtelun välillä oli kohtalainen, tilastollisesti merkitsevä yhteys ( $\mathrm{r}=0,423)$. Mitä enemmän kaltoinkohtelua omaishoitajat kokivat, sitä kuormittuneempia he olivat. Kokonaiskaltoinkohtelun vaihtelu selittää 17,2 \% omaishoitajien kokonaiskuormittuneisuuden vaihtelusta. Kaltoinkohtelu aiheutti omaishoitajille etenkin emotionaalista, mutta myös fyysistä, sosiaalista ja itsensä kehittämisen kuormittuneisuutta. (Taulukko 4.)

Taulukko 4. Kuormittuneisuuden ja kaltoinkohtelun eri ulottuvuuksien välinen yhteys $(\mathrm{N}=316)$.

Kuormittuneisuus

\begin{tabular}{|c|c|c|c|c|c|c|}
\hline Kaltoinkohtelu & $\begin{array}{c}\text { Kokonais- } \\
\text { kuormittuneisuus } \\
\text { r (p-arvo) }\end{array}$ & $\begin{array}{l}\text { Ajallinen } \\
\text { r (p-arvo) }\end{array}$ & $\begin{array}{c}\text { Itsensä } \\
\text { kehittäminen } \\
\mathbf{r} \text { (p-arvo) }\end{array}$ & $\begin{array}{l}\text { Fyysinen } \\
\text { r (p-arvo) }\end{array}$ & $\begin{array}{l}\text { Sosiaalinen } \\
\text { r (p-arvo) }\end{array}$ & $\begin{array}{c}\text { Emotionaalinen } \\
\text { r (p-arvo) }\end{array}$ \\
\hline Kokonaiskaltoinkohtelu & $0,423(<0,001)$ & $0,143(0,011)$ & $0,364(<0,001)$ & $0,317(<0,001)$ & $0,365(<0,001)$ & $0,531(<0,001)$ \\
\hline Fyysinen väkivalta & $0,237(<0,001)$ & $0,134(0,018)$ & $0,204(<0,001)$ & $0,183(0,001)$ & $0,161(0,005)$ & $0,299(<0,001)$ \\
\hline Henkinen väkivalta & $0,344(<0,001)$ & $0,173(0,002)$ & $0,294(<0,001)$ & $0,255(<0,001)$ & $0,249(<0,001)$ & $0,446(<0,001)$ \\
\hline $\begin{array}{l}\text { Taloudellinen } \\
\text { hyväksikäyttö }\end{array}$ & & & & & & $0,199(<0,001)$ \\
\hline $\begin{array}{l}\text { Henkilökohtaisten } \\
\text { oikeuksien } \\
\text { loukkaaminen }\end{array}$ & $0,398(<0,001)$ & $0,136(0,017)$ & $0,357(<0,001)$ & $0,327(<0,001)$ & $0,349(<0,001)$ & $0,422(<0,001)$ \\
\hline Seksuaalinen väkivalta & $0,169(0,003)$ & & & $0,160(0,005)$ & $0,152(0,007)$ & $0,236(<0,001)$ \\
\hline $\begin{array}{l}\text { Sosiaalinen } \\
\text { kaltoinkohtelu }\end{array}$ & $0,350(<0,001)$ & $0,185(0,001)$ & $0,276(<0,001)$ & $0,230(<0,001)$ & $0,305(<0,001)$ & $0,423(<0,001)$ \\
\hline $\begin{array}{l}\text { Hengellinen } \\
\text { kaltoinkohtelu }\end{array}$ & & & & & $0,165(0,003)$ & $0,244(<0,001)$ \\
\hline
\end{tabular}

Spearmanin korrelaatiokerroin 


\section{POHDINTA}

\section{TULOSTEN TARKASTELU}

Tutkimuksella saatiin kattava kuvaus omaishoitajien arjesta ja siihen liittyvistä kuormittuneisuuden ja kaltoinkohtelun kokemuksista. Tutkimus toi uutta tietoa myös omaishoitajien kuormittuneisuuden ja kaltoinkohtelun välisestä yhteydestä, mitä suomalaisella aineistolla ei aikaisemmin ole tutkittu.

Omaishoitajat osoittautuivat kuormittuneiksi, yli kolmasosalla $(36,6 \%)$ kuormittuneisuutta oli usein ja toisinaan sitä oli lähes puolella $(49,8 \%)$ heistä. Kuormittuneisuus oli korkeampaa kuin Toljamon ym. (4) tutkimuksessa, jossa vastaavat luvut olivat $31 \%$ ja $42 \%$. Kansainvälisiin tutkimuksiin verrattuna kuormittuneisuus oli samalla tasolla kuin Paradisen ym. (27) ja Manskowin ym. (31) vuoden 2017 tutkimuksissa, mutta selvästi korkeampaa kuin Hsun ym. (52) $(15 \%)$ ja Manskowin ym. (25) vuoden $2015(16 \%)$ tutkimuksissa. Sen sijaan se oli matalampaa kuin useissa muissa tutkimuksissa, joissa kuormittuneisuus vaihteli $43-50 \%(8,24$, 26,28,30).

Kuten aiemmissa, myös tässä tutkimuksessa omaishoitajat kokivat etenkin ajallista (32,35, $36,46)$, fyysistä $(39,44,78,79)$ ja itsensä kehittämisen $(6,8)$ kuormittuneisuutta. Tulos on ymmärrettävä, sillä hoitamiseen kului paljon aikaa, hoidettavat olivat hyvin riippuvaisia omaishoitajastaan ja tarvitsivat runsaasti apua ja valvontaa. Omaishoitajilla ei myöskään ollut riittävästi mahdollisuutta sosiaalisiin suhteisiin tai omannäköiseen elämään. Lisäksi hoidettavien toimintakyky oli huono, avuntarve erilaisissa arjen toiminnoissa suurta ja monilla myös ympärivuorokautista. Sen sijaan sosiaalista ja emotionaalista kuormittuneisuutta omaishoitajat kokivat edellä mainittuja ulottuvuuksia vähemmän, mikä on todettu myös muissa CBI-mittarilla tehdyissä tutkimuksissa $(23,33,60,80,82)$. Suurin osa omaishoitajista tuli hyvin toimeen muiden perheenjäsenten kanssa ja koki saavansa arvostusta heiltä. Omaishoitajat eivät juurikaan hävenneet hoidettavaansa tai kokeneet katkeruutta tai vihan tunteita hoidettavaansa kohtaan.

Tutkimuksessa tarkasteltiin omaishoitajaa, hoidettavaa ja hoitosuhdetta koskevien taustatekijöiden yhteyttä omaishoitajien kuormittunei- suuteen. Monelta osin tulokset olivat samankaltaisia kuin aikaisemmissa tutkimuksissa. Omaishoitajien ominaisuuksista varsinkin huono terveydentila ja heikentynyt taloudellinen tilanne olivat kuormittuneisuuden taustalla $(32,37,44$, $45)$. Nuoret omaishoitajat kokivat muita ryhmiä enemmän sosiaalista $(26,34,35)$ ja naiset miehiä enemmän emotionaalista kuormittuneisuutta $(23,30)$. Oman puolison, elämänkumppanin tai lapsen hoitaminen kuormitti omaishoitajia fyysisesti $(32,42,43)$, työssäolo hoitamisen ohella ajallisesti ja sosiaalisesti $(34,46,47)$. Hoidettavan ominaisuuksista muistisairaus $(35,36,50)$, käytösoireet $(35,40,46,49,50)$ ja suuri avuntarve $(24,35,37,49)$ osoittautuivat merkittäviksi omaishoitajia kuormittaviksi tekijöiksi, sillä ne olivat yhteydessä lähes kaikkiin kuormittuneisuuden ulottuvuuksiin. Lisäksi hoidettavan miessukupuoli lisäsi omaishoitajien fyysistä ja emotionaalista kuormittuneisuutta $(61,83)$. Hoitosuhdetta koskevista taustatekijöistä etenkin hoitamisen fyysinen ja henkinen raskaus $(43,71)$, hoitamiseen käytetty aika $(32,54)$, omaishoitajien taloudellisen tilanteen heikentyminen $(32,48)$ ja omaishoitajiin muiden taholta kohdistuneet vaatimukset (59) kuormittivat omaishoitajia. Aikaisemmista tutkimustuloksista poiketen omaishoitajien siviilisäädyllä $(34,38)$ tai koulutustasolla (32) ei ollut yhteyttä kuormittuneisuuteen. Poikkeavaa oli myös, että pitkään kestänyt hoitosuhde $(38,54,60,61)$ ja asuminen hoidettavan kanssa $(32,35,40,41,61,83)$ kuormittivat vain vähän omaishoitajia.

Omaishoitajat kokivat myös kaltoinkohtelua hoidettavan taholta, lähes kaksi kolmasosa $(60,3 \%)$ oli kokenut sitä ainakin jossain määrin. Kaltoinkohtelu oli yleisempää kuin vuoden 2015 Kansallisessa rikosuhritutkimuksessa (84) tai AVOW -tutkimuksessa (85), ja sitä esiintyi myös enemmän kuin monissa kansainvälisissä tutkimuksissa $(9,10,67,69,70)$. Kaltoinkohtelun ulottuvuuksista fyysisen väkivallan esiintyvyys oli samaa tasoa kuin Phillipsin (62), matalampaa kuin Kageyaman ym. (68,70), mutta korkeampaa kuin AVOW -tutkimuksessa (85) ja useissa kansainvälisissä tutkimuksissa $(9,63,69,71)$. Omaishoitajiin kohdistunut henkinen ja seksuaalinen väkivalta oli yleisempää, ja taloudellinen hyväksikäyttö vähäisempää kuin edellä mainituissa tutkimuksissa. Omaishoitajien kokeman 
henkilökohtaisten oikeuksien loukkaamisen esiintyvyyttä ei ole kansainvälisesti tutkittu. AVOW -tutkimukseen (85) verrattuna esiintyvyys oli korkeampaa, tosin AVOW -tutkimuksessa ei ollut kyse omaishoitokontekstista. Omaishoitajien kokemasta sosiaalisen ja hengellisen kaltoinkohtelun esiintyvyydestä ei tutkimustietoa ole, joten vertailua aikaisempaan tutkimukseen ei ole mahdollista tehdä.

Tulokset osoittavat, että omaishoitajien kokema kaltoinkohtelu ei juurikaan johdu heidän omista ominaisuuksistaan. Omaishoitajien sukupuoli, siviilisääty, koulutustausta, työssäolo ja omaishoitamisen vuoksi työelämästä poisjäänti eivät tässä, kuten eivät aiemmissakaan tutkimuksissa olleet yhteydessä omaishoitajien kokemaan kaltoinkohteluun $(63,67,70)$. Sen sijaan useat hoidettavaan ja hoitosuhteeseen liittyvät tekijät olivat kaltoinkohtelun taustalla, mikä vastaa aikaisempaa tutkimustietoa. Omaishoitajien taloudellisen tilanteen heikentyminen $(68,70)$, hoidettavan kanssa samassa taloudessa asuminen ja oman puolison tai kumppanin hoitaminen $(62,64,68,72)$ osoittautuivat merkittäviksi kaltoinkohtelun taustatekijöiksi. Toisaalta puolisoaan hoitaneiden omaishoitajien kokema kaltoinkohtelu saattaa olla seurausta parisuhteessa jo aiemminkin esiintyneestä perheväkivallasta $(10,74)$, mitä ei tässä tutkimuksessa ollut mahdollista selvittää.

Hoidettavan miessukupuoli oli yhteydessä omaishoitajien kokemaan henkiseen ja seksuaaliseen väkivaltaan $(9,10,67,70)$. Hoidettavan muistisairaus, masennus sekä erilaiset käytösoireet lisäsivät kaltoinkohtelun kokemisen riskiä usealla kaltoinkohtelun ulottuvuudella. Muistisairauden ja käytösoireiden yhteyden kaltoinkohteluun totesivat myös Wharton ja Ford (10). Sen sijaan hoidettavan masennuksen yhteys omaishoitajien kokemaan kaltoinkohteluun on tuloksena uusi, tiettävästi sitä ei ole aikaisemmin osoitettu. Uutta tutkimustietoa ovat myös hoitamisen henkisen raskauden ja omaishoitajiin kohdistuneiden vaatimusten yhteydet omaishoitajien kokemaan kaltoinkohteluun. Tässä tutkimuksessa omaishoitajat, jotka pitivät hoitamista henkisesti raskaana tai joihin kohdistui vaatimuksia perheeltä, ystäviltä tai ulkopuolisilta henkilöiltä, kokivat monenlaista kaltoinkohtelua hoidettavan taholta. Kuten aikaisemmissa- kin tutkimuksissa hoidettavan iällä $(9,68,70)$ tai suurella avuntarpeella (9), hoitamisen kestolla $(62,63,71)$ tai hoitamiseen käytetyllä päivittäisellä hoitoajalla (67) ei ollut yhteyttä omaishoitajien kokemaan kaltoinkohteluun. Avuntarpeen ja päivittäisen hoitoajan osalta tulosta saattoi selittää hoidettavien huono toimintakyky, jolloin he eivät enää kyenneet kaltoinkohtelemaan omaishoitajaansa.

Tutkimuksen tulokset toivat esiin uutta tietoa omaishoitajien kuormittuneisuuden ja heidän kokemansa kaltoinkohtelun välisestä yhteydestä. Vastaavaa näyttöä ei suomalaisella tai kansainvälisellä aineistolla tiettävästi ole, sillä aiemmissa tutkimuksissa näkökulmana on ollut hoidettavan tietyn sairauden ja siihen liittyneen väkivaltaisen käyttäytymisen yhteys omaishoitajien kuormittuneisuuteen $(10,67,68)$.

Tutkimuksen tuottama tieto omaishoitajien korkeasta kuormittuneisuudesta ja kokemasta kaltoinkohtelusta hoidettavan taholta on huolestuttavaa paitsi inhimillisestä myös yhteiskunnallisesta näkökulmasta. Näyttää siltä, että aivan liian usein omaishoitamiseen liittyy kielteisiä kuormittuneisuuden ja kaltoinkohtelun kokemuksia. Kauan jatkuessaan nämä kokemukset uuvuttavat omaishoitajia, jolloin omaishoitaja ei enää jaksa tehtävässään. Taloudellisesti kestävää ja inhimillistä olisi, että hoidettava saisi asua mahdollisimman pitkään omassa kodissaan, omassa yhteisössään ja läheistensä parissa ja että omaishoitajakin voisi hyvin.

Omaishoitajien kuormittuneisuuden asteen arviointi tulisi olla vakiintunut käytäntö omaishoitajien lakisääteisissä terveystarkastuksissa. Tarvitaan myös keinoja kaltoinkohtelua kokeneiden omaishoitajien tunnistamiseksi ja kaltoinkohtelukokemusten esiin nostamiseksi. Tutkimuksessa käytetyn kaltoinkohtelumittarin kysymyksiä tulisi sisällyttää osaksi käytössä olevia kuormittuneisuusmittareita, jolloin kaltoinkohtelun mittaaminen saataisiin yleisesti hyväksytyksi toimintatavaksi. Tunnistamalla nykyistä paremmin kuormittuneet ja kaltoinkohtelua kokeneet omaishoitajat, voitaisiin suunnitella ja järjestää kullekin omaishoitajalle hänen tarpeisiinsa sopivat palvelut.

Myös omaishoitoyhdistykset voivat hyödyntää tämän tutkimuksen tuottamaa tietoa esimerkiksi järjestäessään ja kehittäessään omaishoi- 
tajille suunnattuja koulutuksia ja valmennuksia, ajaessaan omaishoitajien asiaa ja tukiessaan heitä jaksamaan tärkeässä tehtävässään.

\section{TUTKIMUKSEN EETTISYYS}

Tutkimuseettiset periaatteet ohjasivat koko tutkimusprosessia, ja tutkimusaiheen arkaluontoisuuden vuoksi niihin kiinnitettiin erityistä huomiota. Tutkimusprosessissa noudatettiin tietosuojaa, yleistä huolellisuutta, tarkkuutta ja rehellisyyttä (77).

Tutkimuksen aihevalinta oli eettisesti perusteltua (77), sillä suomalaista tutkimusta omaishoitajien kuormittuneisuudesta viimeisen kymmenen vuoden ajalta on vain vähän, eikä tutkimusta omaishoitajien kokemasta kaltoinkohtelusta hoidettavan taholta ole lainkaan. Myöskään kaltoinkohtelun ja kuormittuneisuuden välistä yhteyttä ei Suomessa ole aikaisemmin tutkittu.

Tutkimukselle ei haettu eettisen toimikunnan lausuntoa, koska tutkimus ei kohdistunut potilaisiin, eikä kyseessä ollut lääketieteellinen tutkimus (86). Tutkimukselle pyydettiin kirjallinen tutkimuslupa omaishoitoyhdistyksiltä, joiden kautta aineistonkeruu toteutettiin (77). Lupaa myöntäessään yhdistykset ovat arvioineet tutkimukseen liittyvät eettiset kysymykset. Tutkimukseen osallistuminen oli vapaaehtoista. Osallistujille kerrottiin tutkimuksen toteutuksesta, kerättyjen tietojen luottamuksellisuudesta sekä siitä, mihin tietoja käytetään. Kyselyyn tuli vastata anonyymisti ja vastaaminen tulkittiin tietoon perustuvaksi suostumukseksi osallistua tutkimukseen (77). Tutkimuksen tulokset raportoitiin avoimesti ja rehellisesti. Muiden tutkijoiden tekemää työtä kunnioitettiin merkitsemällä lähdeviitteet asianmukaisesti (87).

\section{TUTKIMUKSEN LUOTETTAVUUS}

Tutkimuksen luotettavuutta arvioitiin sisäisen ja ulkoisen validiteetin, sisältö- ja rakennevaliditeetin sekä reliabiliteetin avulla (77).

Tutkimuksen kohteena olevaan ilmiöön tutustuttiin tekemällä laaja kirjallisuuskatsaus, jossa tietoa haettiin useista tietokannoista. Tutkimuksessa käytetyt käsitteet ja mittarit perustuivat teoriaan ja kattoivat koko tutkittavan ilmiön. (77.) Tutkimuksen kyselylomake esitestattiin, ja sen sisältö- ja rakennevaliditeetti todettiin hyviksi. Myöskään varsinaisessa tutkimuksessa ei paljastunut virhetulkintoja kysymysten sisällöstä. Kysymyksiin oli vastattu johdonmukaisesti ja huolellisesti.

Omaishoitajien kuormittuneisuutta mitattiin Caregiver Burden Inventory (CBI) -mittarilla, jonka luotettavuutta ovat arvioineet paitsi mittarin kehittäjät myös muutamat muut tutkijat. Mittarin sisäinen johdonmukaisuus (reliabiliteetti), sisältö- ja sisäinen validiteetti on jo aikaisemmin todettu hyväksi $(13,78,80,82)$. CBI-mittaria ei aikaisemmin ole käytetty Suomessa, joten se käännätettiin suomenkielelle virallisen kaksoiskääntämisen käytäntöjen mukaisesti. Mittarin reliabiliteettia arvioitiin tutkimusaineiston analyysivaiheessa Cronbachin alfa -kertoimien avulla tarkistamalla mittarin kaikista väittämistä ja kuormittuneisuuden eri ulottuvuuksia mittaavista väittämistä muodostettujen summamuuttujien sisäinen johdonmukaisuus. Cronbachin alfa -kertoimien arvot vaihtelivat 0,70-0,92, joten mittari todettiin sisäisesti johdonmukaiseksi myös tässä tutkimusaineistossa.

Kaltoinkohtelumittari rakennettiin tätä tutkimusta varten, joten sen reliabiliteettiä ja validitettia ei ole arvioitu aikaisemmin. Mittarin rakennevaliditeetin arvioimiseksi tehtiin eksploratiivinen faktorianalyysi, mutta sillä saatua rakennetta käytettiin vain suuntaa antavana muodostettaessa kaltoinkohtelun eri ulottuvuuksia kuvaavat summamuuttujat. Pääosin summamuuttujat perustuivat tutkimuksen teoreettisiin lähtökohtiin, joten tutkijoiden ennakko-oletukset ovat voineet vaikuttaa syntyneeseen ratkaisuun. Tämä on otettava huomioon tutkimuksen validiteettia arvioitaessa. Summamuuttujien sisäiset johdonmukaisuudet tarkistettiin Cronbachin alfa -kertoimilla. Koska kertoimien arvot vaihtelivat $0,70-0,90$, voidaan mittarin sisäistä johdonmukaisuutta kuitenkin pitää hyvänä. (77.) Mittarin sisäistä validiteettia ei tämän yhden tutkimuksen perusteella ole mahdollista arvioida, mutta validiteettia tukevat vastausten johdonmukaisuus sekä keskiarvoja ja mediaaneja lähellä olleet hajontaluvut (88).

Tutkimuksen kohdejoukkona oli viiden omaishoitoyhdistyksen jäsenet. Tutkimuksen ulkoisen validiteetin parantamiseksi vastaukset pyydettiin vain niiltä, joilla oli kokemusta omaishoitajana toimimisesta. Yhdistysten kannattajajäsenet rajattiin tietoisesti pois vastaajien joukosta. Tällöin 
oli mahdollista saada mahdollisimman edustava ja pätevä kuvaus tutkimuksen kohteena olevasta ilmiöstä. Tutkimuksen vastausprosentti oli $53,7 \%$, jota postikyselylle voidaan pitää varsin hyvänä (89). Vastausten määrä oli myös riittävä tilastollisten analyysien tekemiseen (90). Tutkimusaineisto edusti kattavasti kyseisten omaishoitoyhdistysten jäseniä, joten tulosten voidaan ajatella olevan yleistettävissä tähän ryhmään. Luotettavuutta paransi myös kahden tutkijan yhteistyöskentely, tutkimuksen suorittamisen johdonmukaisuus, huolellisuus ja tarkkuus koko tutkimusprosessin ajan.

Tulosten yleistämiseen edellä mainittua ryhmää laajemmalle on kuitenkin suhtauduttava varauksella. Koska demograafisia tilastotietoja Suomessa toimivien omaishoitoyhdistysten jäsenistä eli tutkimuksen perusjoukosta ei ollut saatavilla, systemaattista otantaa tai arvontaa ei ollut mahdollista käyttää otoksen valitsemistapana. Tämän vuoksi tutkimuksen kohdejoukko ei välttämättä vastaa koko perusjoukkoa tutkittavien ominaisuuksien suhteen. Demograafisten tilastotietojen puuttumisen vuoksi myöskään katoanalyysiä ei ollut mahdollista tehdä. Tiedossa ei siis ollut, oliko vastaamatta jättäminen systemaattista omaishoitajan sukupuolen, iän, koulutustason tai jonkun muun seikan vuoksi. Tuotetun tiedon avulla on kuitenkin mahdollista lisätä ymmärrystä sekä tutkitun ilmiön luonteesta että esiintymisestä. (77.)

\section{JOHTOPÄÄTÖKSET}

Omaishoitajat ovat kuormittuneita, ja he kokevat etenkin ajallista kuormittuneisuutta, mutta paljon myös fyysistä ja itsensä kehittämisen kuormittuneisuutta. Edellisiä vähemmän heillä on sosiaalista ja emotionaalista kuormittuneisuutta. Niin ikään kaltoinkohtelun kokeminen hoidettavan taholta on omaishoitajilla yleistä. Varsinkin henkistä väkivaltaa ja henkilökohtaisten oikeuksien loukkaamista kokee moni heistä. Lisäksi usea kokee sosiaalista kaltoinkohtelua ja fyysistä väkivaltaa. Vähiten he kokevat seksuaalista väkivaltaa, hengellistä kaltoinkohtelua ja taloudellista hyväksikäyttöä. Omaishoitajien kokemalla kaltoinkohtelulla on yhteys heidän kuormittuneisuuteensa. Mitä enemmän he kokevat kaltoinkohtelua, sitä kuormittuneempia he ovat. Kaltoinkohtelu aiheuttaa heille etenkin emotio- naalista, mutta myös fyysistä, sosiaalista ja itsensä kehittämisen kuormittuneisuutta. Omaishoitajien kuormittuneisuuden ja heidän hoidettavansa taholta kokeman kaltoinkohtelun taustalla on useita omaishoitajaan, hoidettavaan ja hoitosuhteeseen liittyviä taustatekijöitä.

Tutkimus keskittyi kuvailemaan omaishoitajien kuormittuneisuutta ja heidän kokemaansa kaltoinkohtelua hoidettavan taholta, taustatekijöiden yhteyttä näihin ilmiöihin ja ilmiöiden yhteyttä toisiinsa. Tutkimuksessa osoitettiin edellä mainittuja yhteyksiä, mutta jatkotutkimusta tarvitaan selvien syy-seuraussuhteiden löytämiseksi. Niin ikään hyödyllistä on selvittää muidenkin taustatekijöiden yhteyttä omaishoitajien kuormittuneisuuteen ja heidän kokemaansa kaltoinkohteluun. Ovatko esimerkiksi omaishoitajien omat sairaudet, oma käyttäytyminen, parisuhteessa aikaisemmin esiintynyt väkivalta tai kumppaneiden väliset vuorovaikutusongelmat yhteydessä näihin ilmiöihin? Lisätutkimusta tarvitaan myös hoidettavan masennuksen yhteydestä omaishoitajien kokemaan kaltoinkohteluun. Lisäksi tärkeää on tutkia, onko kaltoinkohtelu omaishoitoperheessä molemmin puolista, kokevatko omaishoitajat kaltoinkohtelua muidenkin taholta ja kaltoinkohtelevatko kuormittuneet omaishoitajat hoidettavaansa.

Tutkimuksessa käytettyjä kuormittuneisuusja kaltoinkohtelumittareita ei ole validoitu suomalaisella aineistolla, joten jatkotutkimuksen tavoitteena voisi olla mittareiden validointi ja CBI-mittarin jatkokehittäminen lisäämällä siihen omaishoitajien psyykkistä ja psykososiaalista kuormittuneisuutta mittaavat kysymykset.

Tässä tutkimuksessa kuormittuneisuus- ja kaltoinkohtelumittareita käytettiin kuvaileviin analyyseihin sekä alustavaan hahmotukseen yksittäisten tekijöiden yhteyksistä omaishoitajien kokeman kuormittuneisuuden ja kaltoinkohtelun eri ulottuvuuksiin. Jatkotutkimuksessa eri taustatekijöiden suhteellista merkitystä omaishoitajien kokemaan kuormittuneisuuteen ja kaltoinkohteluun olisi tarpeen arvioida esimerkiksi regressioanalyysin avulla. Lisäksi omaishoitajien tuen tarvetta ja tukea itsessään tulee tutkia lisää.

\section{RAHOITTAJAT:}

Tutkimusta ei ole rahoittanut mikään taho. 


\section{KIRJOITTAJIEN KONTRIBUUTIOT:}

Latomäki ja Runsala ovat suunnitelleet tutkimuksen, keränneet ja analysoineet aineiston sekä laatineet käsikirjoituksen. Koivisto on osallistunut tutkimuksen suunnitteluun, aineiston analysoin- tiin ja kommentointiin. Kylmä ja Paavilainen ovat osallistuneet tutkimuksen suunnitteluun, aineiston analysointiin, käsikirjoituksen laadintaan ja kommentointiin. Kaikki kirjoittajat ovat hyväksyneet lopullisen käsikirjoituksen.

\section{Latomäki, M., Runsala, E., Koivisto,A-M., Kylmä, J., Paavilainen, E. Burden and Abuse Experienced by Caregivers. Sosiaalilääketieteellinen aikakauslehti - Journal of Social Medicine 2020: 57: I00-I 23.}

The study assess the burden and abuse experienced by family caregivers, and the connection between the burden and caregiver abuse by the care receivers. The data were collected through a survey from the members of five different caregiver associations from members whose care receivers were at least 18 years old. The response rate was $53.7 \%(\mathrm{~N}=316)$.

The caregivers experienced a considerable amount of burden, mostly time-dependence burden, developmental burden and physical burden, and a lesser amount of social or emotional burden. Abuse by care receivers was common, particularly manifesting as psychological violence and violation of personal rights. Many had also experienced social abuse or physical violence. The least common forms of abuse experienced were sexual violence, financial abuse and spiritual abuse.

The factors related to the burden of caregivers were their health and financial situation, the care receivers' possible memory disorder, behavioural disorders or their daily need of help, the time spent caring for the care receivers, the physical and psychological burden caused by caregiving duties, and the demands by family members, friends and others. The abuse experienced by caregivers was connected to: living with the care receiver; caring for one's spouse or life partner; the memory disorder; depression and behavioural disorders of the care receiver; a poor financial situation of the caregiver; and demands by others. The abuse and burden experienced by caregivers are directly connected. The more they experienced abuse, the more they experienced burden. Caregiver abuse caused particularly emotional burden, but also physical, social and developmental burden.

Keywords: family caregiver, caregiver, care receiver, caregiving relationship, burden, abuse

Saapunut 18.10.2018

Hyväksytty 19.10.2019

\section{LÄHTEET}

(1) Omaishoitajat ja läheiset -liitto ry. Mitä on omaishoito? Luettu 10.6.2017. https:// omaishoitajat.fi/omaishoidon-tietopaketti/mitaon-omaishoito/

(2) Shemeikka R, Buchert U, Pitkänen S, ym. Omaishoitajien tarvitsemat tukitoimet tehtävässä selviytymiseen. Valtioneuvoston selvitys- ja tutkimustoiminnan julkaisusarja 37/2017. Valtioneuvoston kanslia. Luettu 12.4.2017. https://omaishoitajat. fi/wp-content/uploads/2017/03/37 Omaishoitajien-tarvitsemat-tukitoimetteht $\% \mathrm{C} 3 \% \mathrm{~A} 4 \mathrm{v} \% \mathrm{C} 3 \% \mathrm{~A} 4 \mathrm{ss} \% \mathrm{C} 3 \% \mathrm{~A} 4-$ selviytymiseen_.pdf

(3) Kehusmaa S. Hoidon menoja hillitsemässä. Heikkokuntoisten kotona asuvien ikäihmisten palvelujen käyttö, omaishoito ja kuntoutus. Kela, sosiaali- ja terveysturvan tutkimuksia 131. Helsinki. 2014. Luettu 13.3.2017. https://helda. helsinki.fi/bitstream/handle/10138/135650/ Tutkimuksia131.pdf?sequence

(4) Toljamo M, Perälä ML, Laukkala H. Impact of caregiving on Finnish family caregivers. Scand J Caring Sci 2012;26(2):211-218. doi: 10.1111/j.1471-6712.2011.00919.x

(5) Jansen JE, Lysaker PH, Harder S, ym. Positive and negative caregiver experiences in firstepisode psychosis: Emotional over involvement, wellbeing and metacognition. Psychol Psychother 2014;87(3):298-310. doi: $10.1111 /$ papt.12014

(6) Cohen SA, Cook S, Kelley L, ym. Psychosocial factors of caregiver burden in child caregivers: results from the new national study of caregiving. Health and Quality of Life Outcomes 2015;13(1):1-6. doi: 10.1186/s12955-015-0317-2

(7) Ervin K, Pallant J, Reid C. Caregiver distress in dementia in rural Victoria. Australas J Ageing 2015;34(4): 235-240. doi: 10.1111/ajag.12158 
(8) Unson C, Flynn D, Haymes E, ym. Predictors of types of caregiver burden. Soc Work Ment Health 2016;14(1):82-101. doi: 10.1080/15332985.2015.1080206

(9) Cooper C, Selwood A, Blanchard M, ym. Abusive behaviour experienced by family carers from people with dementia: the CARD (caring for relatives with dementia) study. J Neurol Neurosurg Psychiatry 2010;81(6):592-596. doi: 10.1136/jnnp.2009.190934

(10) Wharton TC, Ford BK. What is known about dementia care recipient violence and aggression against caregivers? J Gerontol Soc Work 2014;57(5):460-477.

doi: 10.1080/01634372.2014.882466

(11) Eurofound. Third European Quality of Life Survey - Quality of life in Europe: Social inequalities. Publications Office of the European Union. Luxembourg. 2013. doi:10.2806/45943.

(12) Laki omaishoidon tuesta 2.12.2005/937. http:// www.finlex.fi/fi/laki/ajantasa/2005/ 20050937

(13) Novak M, Guest C. Application of a multidimensional Caregiver Burden Inventory. Gerontologist 1989;29(6):798-803. doi: 10.1093/geront/29.6.798

(14) WHO. European report on preventing elder maltreatment. 2011. Luettu 10.1.2017. http://www.euro.who.int/_data/assets/pdf_ file/0010/144676/e95110.pdf?ua=1

(15) Valvira. Kaltoinkohtelu ympärivuorokautisissa vanhustenhuollon yksiköissä työntekijöiden havainnoimana. Valviran kysely 25.2.18.3.2016. Selvityksiä 1:2016. Helsinki. Dnro 5144/05.00.00.04/2016.

(16) Kirsi T. Rakasta, kärsi ja kirjoita. Tutkimus dementoitunutta puolisoaan hoitaneiden naisten ja miesten hoitokokemuksesta. Acta Universitatis Tamperensis 1051. Tampere University Press. Tampere; 2004. http://urn.fi/urn:isbn:951-44-6152-5

(17) Sointu L. Hoiva suhteessa. Tutkimus puolisoaan hoivaavien arjesta. Acta Universitatis Tamperensis 2195. Tampere University Press. Tampere; 2016. http://urn.fi/URN:ISBN:978-952-03-0190-3

(18) Tikkanen U. Omaishoidon arki: tutkimus hoivan sidoksista. Valtiotieteellisen tiedekunnan julkaisuja. Helsingin yliopisto. Helsinki; 2016. http://urn.fi/URN:NBN:fi:ELE-1774234

(19) Jolanki O. Työssäkäyvät omaishoitajat. Gerontologia 2010; 24(4):349-350.

(20) Juntunen K, Salminen A-L. Omaishoitajan jaksamisen ja tuen tarpeen arviointi. COPEindeksi suomalaisen sosiaali-ja terveydenhuollon käyttöön. Sosiaali- ja terveysturvan selosteita 78/2011. Kela. Kelan tutkimusosasto. Helsinki; 2011. http://hdl.handle.net/10138/28272

(21) Leinonen A. Informal family carers and lack of personal time: Descriptions of being outside the sphere of formal help. Nordic Social Work Research 2011;1(2):91-108. doi: 10.1080/2156857X.2011.601142
(22) Kauppinen K, Silfver-Kuhalampi M. Työssäkäynnin ja läheishoivan yhteensovittaminen - kyselytutkimuksen tuloksia. Teoksessa: Kauppinen K, Silfver-Kuhalampi M. (toim.) Työssäkäynti ja läheis- ja omaishoiva. Työssä jaksamisen ja jatkamisen tukeminen. Sosiaalitieteiden laitoksen julkaisuja. Helsingin yliopisto. Helsinki; 2015;12:21-75.

(23) Zucchella C, Bartolo M, Pasotti C, ym. Caregiver burden and coping in early-stage Alzheimer disease. Alzheimer Dis Assoc Disord 2012:26(1):55-60. doi: 10.1097/WAD.0b013e31821aa6de

(24) Brodaty H, Woodward M, Boundy K, ym. Prevalence and predictors of burden in caregivers of people with dementia. Am J Geriatr Psychiatry 2014;22(8):756-765. doi: 10.1016/j.jagp.2013.05.004

(25) Manskow US, Sigurdardottir S, Røe C, ym. Factors affecting caregiver burden 1 year after severe traumatic brain injury: A prospective nationwide multicenter study. J Head Trauma Rehabil 2015;30(6):411-423. doi: 10.1097/HTR.0000000000000085

(26) Mougias AA, Politis A, Mougias MA, ym. The burden of caring for patients with dementia and its predictors. Psychiatriki 2015;26(1):28-37. PMID: 25880381

(27) Paradise M, McCade D, Hickie IB, ym. Caregiver burden in mild cognitive impairment. Aging Ment Health 2015;19(1):72-78. doi: 10.1080/13607863.2014.915922

(28) Bayen E, Jourdan C, Ghout I, ym. Objective and Subjective Burden of Informal Caregivers 4 Years After a Severe Traumatic Brain Injury: Results From the PariS-TBI Study. J Head Trauma Rehabil 2016;31(5):E59-E67. doi: 10.1097/HTR.0000000000000079

(29) Kruithof WJ, Post MWM, van Mierlo ML, ym. Caregiver burden and emotional problems in partners of stroke patients at two months and one year post-stroke: Determinants and prediction. Patient Educ Couns 2016;99(10):1632-1640. doi: $10.1016 /$ j.pec.2016.04.007

(30) Castellano-Tejedor C, Lusilla-Palacios P. A study of burden of care and its correlates among family members supporting relatives and loved-ones with traumatic spinal cord injuries. Clin Rehabil 2017;31(7):948-956. doi: 10.1177/0269215517709330

(31) Manskow US, Friborg O, Røe C, ym. Patterns of change and stability in caregiver burden and life satisfaction from 1 to 2 years after severe traumatic brain injury: A Norwegian longitudinal study. NeuroRehabilitation 2017;40(2):211-222. doi: 10.3233/NRE-161406

(32) Adelman RD, Tmanova LL, Delgado D, ym. Caregiver burden: a clinical review. JAMA 2014;311(10):1052-1060. doi: 10.1001/jama.2014.304 
(33) Iavarone A, Ziello AR, Pastore F, ym. Caregiver burden and coping strategies in caregivers of patients with Alzheimer's disease. Neuropsychiatr Dis Treat 2014;10:1407-1413. doi: 10.2147/NDT.S58063

(34) Casado-Mejía R, Ruiz-Arias E. Influence of gender and care strategy in family caregivers strain: A cross-sectional study. J Nurs Scholarsh 2016;48(6):587-597. doi: 10.1111/jnu.12256

(35) Garre-Olmo J, Vilalta-Franch J, Calvó-Perxas $\mathrm{L}, \mathrm{ym}$. A path analysis of patient dependence and caregiver burden in Alzheimer's disease. Int Psychogeriatr 2016;28(7):1133-1141. doi: $10.1017 / S 1041610216000223$

(36) Sutcliffe CL, Giebel CM, Jolley D, ym. Experience of burden in carers of people with dementia on the margins of long-term care. Int J Geriatr Psychiatry 2016;31(2):101-108. doi: 10.1002/gps.4295

(37) Laporte Uribe F, Heinrich S, Wolf-Ostermann $\mathrm{K}$, ym. Caregiver burden assessed in dementia care networks in Germany: fidings from the DemNet-D study baseline. Aging Ment Health 2017;21(9):926-937. doi: 10.1080/13607863.2016.1181713

(38) Bademli K, Lök N, Kiliç Kaya A. Relationship between caregiving burden and anger level in primary caregivers of individuals with chronic mental illness. Arch Psychiatr Nurs 2017;31(3):263-268. doi: 10.1016/j.apnu.2016.12.001

(39) Gibbons C, Creese J, Tran M, ym. The psychological and health consequences of caring for a spouse with dementia: A critical comparison of husbands and wives. J Women Aging 2014;26(1):3-21. doi: 10.1080/08952841.2014.854571

(40) Sousa MFB, Santos RL, Turró-Garriga $\mathrm{O}, \mathrm{ym}$. Factors associated with caregiver burden: Comparative study between Brazilian and Spanish caregivers of patients with Alzheimer's disease (AD). Int Psychogeriatr 2016;28(8):1363-1374. doi: $10.1017 / S 1041610216000508$

(41) Conde-Sala JL, Garre-Olmo J, Turró-Garriga O, ym. Differential features of burden between spouse and adult-child caregivers of patients with Alzheimer's disease: An exploratory comparative design. Int J Nurs Stud 2010;47(10):1262-1273. doi: 10.1016/j.ijnurstu.2010.03.001

(42) Dawson F, Shanahan S, Fitzsimons E, ym. The impact of caring for an adult with intellectual disability and psychiatric comorbidity on carer stress and psychological distress. J Intellect Disabil Res 2016;60(6):553-63. doi: 10.1111/jir.12269

(43) Totsika V, Hastings RP, Vagenas D. Informal caregivers of people with an intellectual disability in England: health, quality of life, and impact of caring. Health Soc Care Community 2017;25(3):951-961. doi: 10.1111/hsc.12393

(44) Ferrera M, Langiano E, Di Brango T, ym. Prevalence of stress, anxiety and depression in with Alzheimer caregivers. Health Qual Life Outcomes 2018;6(1):93-97.

doi: 10.1186/1477-7525-6-93

(45) Drutyte G, João Forjaz M, Rodriguez-Blazquez C, ym. What impacts on the stress symptoms of Parkinson's carers? Results from the Parkinson's UK Members' Survey. Disabil Rehabil 2014;36(3):199-204. doi: 10.3109/09638288.2013.782363

(46) Thyrian JR, Winter P, Reimann M, ym. Relatives' burden of caring for people screened positive for dementia in primary care. Results of the DelpHi study. Z Gerontol Geriatr 2017;50(1):4-13. doi: 10.1007/s00391-016-1119-9

(47) Peña-Longobardo LM, Oliva-Moreno J. Caregiver burden in Alzheimer's disease patients in Spain. J Alzheimers Dis 2015;43(4):1293-302. doi: $10.3233 / J A D-141374$

(48) Lee DR, McKeith I, Mosimann U, ym. Examining carer stress in dementia: the role of subtype diagnosis and neuropsychiatric symptoms. Int J Geriatr Psychiatry 2013;28(2):135-141. doi: 10.1002/gps.3799

(49) Dauphinot V, Ravier A, Novais T, ym. Riskfactors of caregiver burden evolution, for patients with subjective cognitive decline or neurocognitive disorders: A longitudinal analysis. J Am Med Dir Assoc 2016;17(11):1037-1043. doi: 10.1016/j.jamda.2016.07.003

(50) Svensboe E, Terum T, Testad I, ym. Caregiver burden in family carers of people with dementia with Lewy bodies and Alzheimer's disease. Int J Geriatr Psychiatry 2016;31(9):1075-1083. doi: $10.1002 /$ gps.4433

(51) del-Pino-Casado R, Frías-Osuna A, PalominoMoral PA ym. Coping and subjective burden in caregivers of older relatives: a quantitative systematic review. J Adv Nurs 2011;67(11):2311-2322. doi: 10.1111/j.1365-2648.2011.05725.x.

(52) Hsu T, Loscalzo M, Ramani R, ym. Factors associated with high burden in caregivers of older adults with cancer. Cancer 2014;120(18):2927-2935. doi: $10.1002 /$ cncr. 28765

(53) Schrank B, Ebert-Vogel A, Amering M, ym. Gender differences in caregiver burden and its determinants in family members of terminally ill cancer patients. Psychooncology 2016;25(7):808-814. doi: 10.1002/pon.4005

(54) Zhong M, Peppard R, Velakoulis D ym. The relationship between specific cognitive defects and burden of care in Parkinson's disease. Int Psychogeriatr 2016;28(2):275-281. doi: $10.1017 / S 1041610215001593$

(55) Jaracz K, Grabowska-Fudala B, Górna K, $\mathrm{ym}$. Burden in caregivers of long-term stroke survivors: Prevalence and determinants at 6 months and 5 years after stroke. Patient Educ Couns 2015;98(8):1011-1016. doi: 10.1016/j.pec.2015.04.008 
(56) Slaunwhite AK, Ronis ST, Sun Y, ym. The emotional health and well-being of Canadians who care for persons with mental health or addictions problems. Health \& Soc Care Community 2016;25(3):840-847. doi: $10.1111 /$ hsc. 12366

(57) Santos-García D, de la Fuente-Fernández R. Factors contributing to caregivers' stress and burden in Parkinson's disease. Acta Neurol Scand 2015;131(4):203-210. doi: 10.1111/ane.12305

(58) Kamiya M, Sakurai T, Ogama N, ym. Factors associated with increased caregivers' burden in several cognitive stages of Alzheimer's disease. Geriatr Gerontol Int 2014;14(2):45-55. doi: 10.1111/ggi.12260

(59) McCann TV, Bamberg J, McCann F. Family carers' experience of caring for an older pa-rent with severe and persistent mental illness. Int J Ment Health Nurs 2015;24(3):203-212. doi: 10.1111/inm.12135

(60) D’Onofrio G, Sancarlo D, Addante F, ym. Caregiver burden characterization in patients with Alzheimer's disease or vascular dementia. Int J Geriatr Psychiatry 2015;30(9):891-899. doi: 10.1002/gps.4232

(61) Litzelman K, Skinner HG, Gagnon RE, ym. The relationship among caregiving characteristics, caregiver strain, and health-related quality of life: Evidence from the Survey of the Health of Wisconsin. Qual Life Res 2015;24(6):1397-1406. doi: 10.1007/s11136-014-0874-6

(62) Phillips LR. Abuse of Aging Caregivers Test of a Nursing Intervention. ANS Adv Nurs Sci 2008;31(2):164-181. doi: 10.1097/01.ANS.0000319566.06879.e8

(63) Erosa NA, Elliott TR, Berry JW, ym. Verbal and physical abuse experienced by fa-mily caregivers of adults with severe disabilities. Ital J Public Health 2010;7(2):76-84. doi: $10.2427 / 5732$

(64) Hanzawa S, Bae JK, Bae YJ, ym. Psychological impact on caregivers traumatized by the violent behavior of a family member with schizophrenia. Asian J Psychiatr 2013;6(1):46-51. doi: 10.1016/j.ajp.2012.08.009

(65) Seeman M. Bad, burdened or ill? Characterizing the spouses of women with schizophrenia. Int J Soc Psychiatry 2013;59(8):805-810. doi: $10.1177 / 0020764012456818$

(66) Mei-Chi H, Chun-Hsien T. Adult patients with schizophrenia using violence towards their parents: a phenomenological study of views and experiences of violence in parent-child dyads. J Adv Nurs 2014;70(2):336-349. doi: 10.1111/jan.12194

(67) Onwumere J, Grice S, Garety P, ym. Caregiver Reports of Patient-Initiated Violence in Psychosis. Can J Psychiatry 2014;59(7):376-384. doi: 10.1177/070674371405900705

(68) Kageyama M, Solomon P, Yokoyama K. Psychological Distress and Violence Towards Parents of Patients with Schizophrenia. Arch
Psychiatr Nurs 2016;30(5):614-619. doi: 10.1016/j.apnu.2016.02.003

(69) Phillips LR, Torres de Ardon E, Solis Briones G. Abuse of Female Caregivers by Care Recipients: Another Form of Elder Abuse. J Elder Abuse Negl 2000;12(3/4):123-143. doi: 10.1300/J084v12n03_06

(70) Kageyama M, Solomon P, Kita S, ym. Factors related to physical violence experienced by parents of persons with Schizophrenia in Japan. Psychiatry Res 2016;243(30):439-445. doi: 10.1016/j.psychres.2016.06.036

(71) Özcan NK, Boyacıoğlu NE, Sertçelik E. Reciprocal Abuse: Elder Neglect and Abuse by Primary Caregivers and Caregiver Burden and Abuse in Turkey. Arch Psychiatr Nurs 2017;31(2):177-182.

doi: 10.1016/j.apnu.2016.09.011

(72) Salwen JK, Gray A, Mona LR. Personal Assistance, Disability, and Intimate Partner Violence: A Guide for Healthcare Providers. Rehabil Psychol 2016;61(4):417-429. doi:10.1037/rep0000111

(73) Jackson SL, Hafemeister TL. Theorybased models enhancing the understanding of four types of elder maltreatment. Int Rev Vict 2016;22(3):289-320. doi:10.1177/0269758016630887

(74) Koenig T, Rinfrette E, Lutz W. Female caregivers reflections on ethical decision-making: the intersection of domestic violence and elder care. Clin Soc Work J 2006;34(3):361-371. doi:10.1007/s10615-005-0023-3

(75) Lowyck B, De Hert M, Peeters E, ym. A study of the family burden of 150 family members of schizophrenic patients. Eur Psychiatry 2004;19(7):395-401. doi:10.1016/j. eurpsy.2004.04.006

(76) Terveyden ja hyvinvoinnin laitos. Eurooppalainen tutkimus ikääntyvien naisten elämänlaadusta ja heihin kohdistuvasta kaltoinkohtelusta ja väkivallasta. 2010. Luettu 22.1.2017. https://www.thl.fi/en/web/ thlfi-en/research-and-expertwork/projects-andprogrammes/avow-study/outcomes-and-reports/ questionnaire

(77) Gray JR, Grove SK, Sutherland S. The Practice of Nursing Research; Appraisal, Synthesis, and Generation of Evidence. 8 th edition. W.B. Saunders Company. St. Louis, Missouri; 2017.

(78) Caserta MS, Lund DA, Wright SD. Exploring the caregiver burden inventory (CBI): further evidence for a multidimensional view of burden. Int J Aging Hum Dev 1996;43(1):21-34. doi:10.2190/2DKF-292P-A53W-W0A8

(79) Fianco A, Sartori RDG, Negri L, ym. The relationship between burden and well-being among caregivers of Italian people diagnosed with severe neuromotor and cognitive disorders. Res Dev Disabil 2015;39:43-54. doi: 10.1016/j.ridd.2015.01.006

(80) Valer DB, Aires M, Fengler FL, ym. Adaptation and validation of the Caregiver Burden Inventory 
for use with caregivers of elderly individuals. Rev Lat Am Enfermagem 2015;23(1):130-138. doi: 10.1590/0104-1169.3357.2534

(81) Sanders AE. Caregiver stress and the patient with dementia. Continuum (Minneap Minn) 2016;22(2):619-625.

doi: 10.1212/CON.0000000000000301

(82) Chou K-R, Jiann-Chyun L, Chu H. The reliability and validity of the Chinese version of the Caregiver Burden Inventory. Nurs Res 2002;51(5):324-331. doi: 10.1097/00006199-200209000-00009

(83) Raccichini A, Spazzafumo L, Castellani S, ym. Living with Mild to Moderate Alzheimer Patients Increases the Caregiver's Burden at 6 Months. Am J Alzheimers Dis Other Demen 2015;30(5):463-467. doi:10.1177/1533317514568339

(84) Danielsson P, Kääriäinen J. Suomalaiset väkivallan ja omaisuusrikosten kohteena 2015

- Kansallisen rikosuhritutkimuksen tuloksia. Katsauksia 13/2016. Helsingin yliopisto. Valtiotieteellinen tiedekunta. Kriminologian ja oikeuspolitiikan instituutti. Helsinki. http://hdl.handle.net/10138/161960

(85) Luoma ML, Koivusilta M, Lang G, ym. Prevalence Study of Abuse and Violence against Older Women. Results of a Multi-cultural Survey Conducted in Austria, Belgium, Finland, Lithuania, and Portugal. 2011. doi: 10.13140/RG.2.1.4646.4166

(86) Tutkimuseettinen neuvottelukunta. Eettinen ennakkoarviointi ihmistieteissä. 2017. Luettu 9.7.2017. http://www.tenk.fi/fi/eettinenennakkoarviointi-ihmistieteissa

(87) Tutkimuseettinen neuvottelukunta. Hyvä tieteellinen käytäntö ja sen loukkausepäilyjen käsitteleminen Suomessa. 2012. Luettu 9.7.2017. http://www.tenk.fi/sites/tenk.fi/files/HTK_ ohje_2012.pdf
(88) Nummenmaa L. 2009. Käyttäytymistieteiden tilastolliset menetelmät. Kustannusosakeyhtiö Tammi. Helsinki.

(89) KvantiMOTV. Postikyselyaineiston kokoaminen. 2017. Luettu 10.7.2017. http://www.fsd.uta.fi/ menetelmaopetus/postikysely/postikysely.html

(90) Kellar S, Kelvin E. Munro's Statistical methods for health care research. 6. edition. Wolters Kluwer Health/Lippincott Williams \& Wilkins. Philadelphia; 2013.

\section{Mervi LatomäKI}

TtM, hoivatyönjohtaja

Suupohjan peruspalveluliikelaitoskuntaybtymä

EILA RUNSALA

TtM, kotihoidon johtaja

Suupohjan peruspalveluliikelaitoskuntayhtymä

Anna-Maija Koivisto

FM, yliopisto-opettaja

Tampereen yliopisto

Yhteiskuntatieteiden tiedekunta

\section{JARI KYLMÄ}

FT, dosentti, yliopistonlehtori

Tampereen yliopisto

Yhteiskuntatieteiden tiedekunta

Eija Paavilainen

TtT, professori

Tampereen yliopisto

Yhteiskuntatieteiden tiedekunta

Etelä-Pohjanmaan sairaanhoitopiiri 


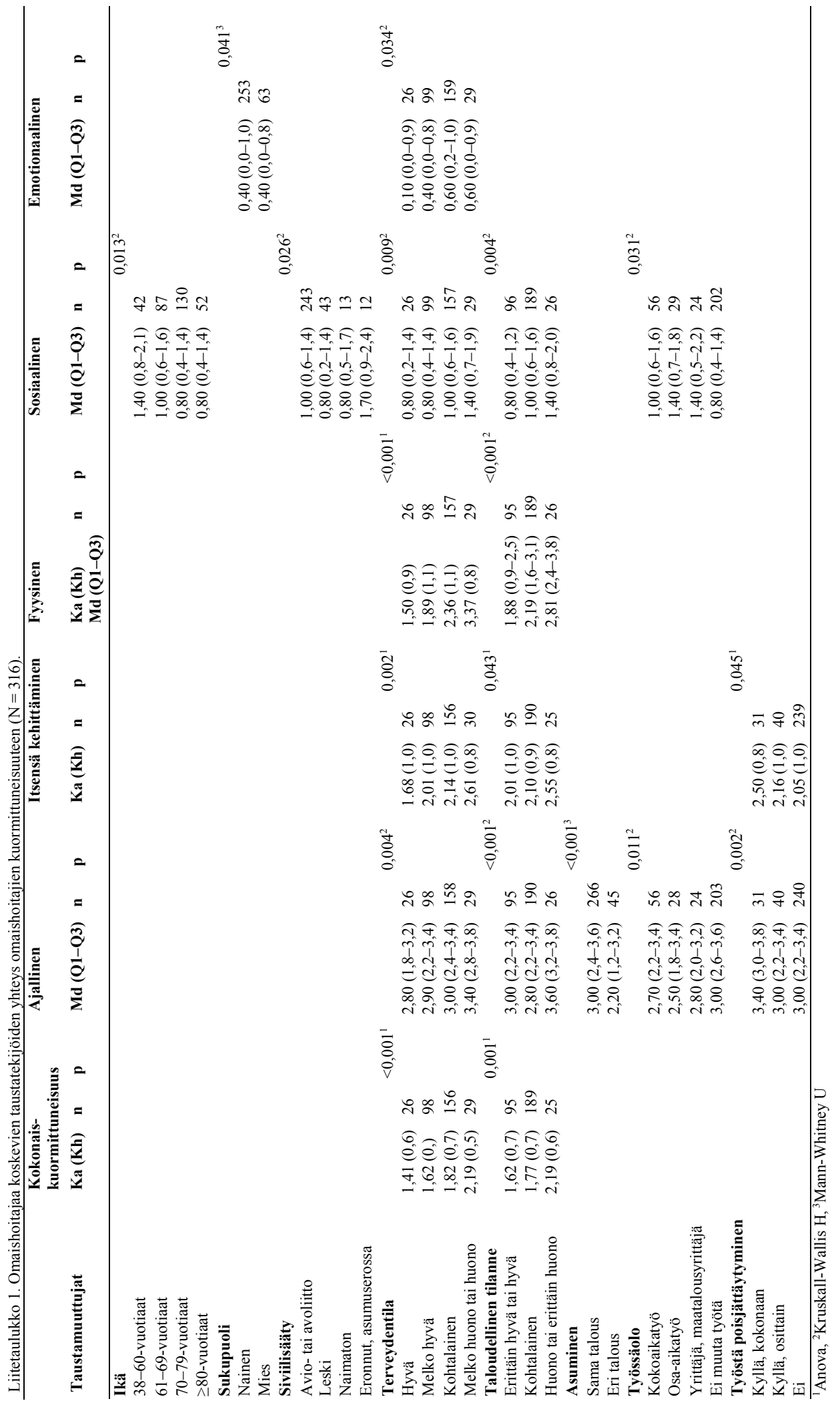




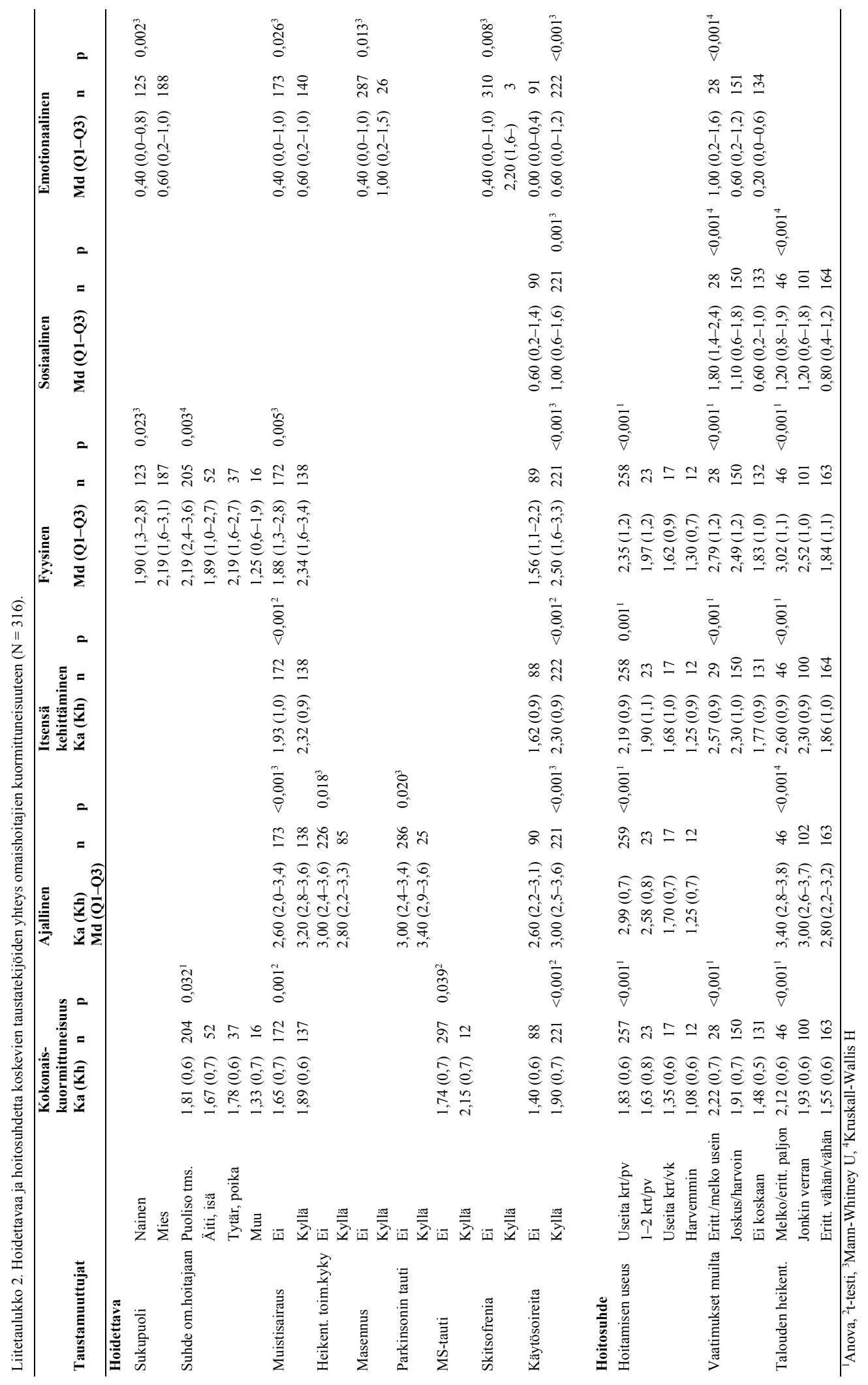


Liitetaulukko 3. Omaishoitajaa, hoidettavaa ja hoitosuhdetta koskevien taustatekijöiden yhteys kaltoinkohteluun $(\mathrm{N}=316)$.

\begin{tabular}{|c|c|c|c|c|c|}
\hline Kaltoinkohtelun ulottuvuus & Taustamuuttuja & Muuttujan luokat & $\mathbf{n}$ & Md (Q1-Q3) & p-arvo \\
\hline \multirow[t]{24}{*}{ Kokonaiskaltoinkohtelu } & \multicolumn{5}{|l|}{ Omaishoitaja } \\
\hline & \multirow[t]{3}{*}{ Taloudellinen tilanne } & Erittäin hyvä tai hyvä & 96 & $1,03(1,0-1,2)$ & $0,042^{1}$ \\
\hline & & Kohtalainen & 191 & $1,06(1,0-1,3)$ & \\
\hline & & Huono tai erittäin huono & 26 & $1,13(1,0-1,5)$ & \\
\hline & \multirow{2}{*}{ Asuminen hoidettavan kanssa } & Sama talous & 267 & $1,06(1,0-1,3)$ & $0,021^{2}$ \\
\hline & & Eri talous & 46 & $1,02(1,0-1,1)$ & \\
\hline & \multicolumn{5}{|l|}{ Hoidettava } \\
\hline & \multirow[t]{4}{*}{ Suhde omaishoitajaan } & Puoliso tms. & 206 & $1,10(1,0-1,3)$ & $0,010^{1}$ \\
\hline & & Äiti, isä & 53 & $1,00(1,0-1,1)$ & \\
\hline & & Tytär, poika & 38 & $1,05(1,0-1,1)$ & \\
\hline & & Muu & 16 & $1,06(1,0-1,2)$ & \\
\hline & \multirow[t]{2}{*}{ Muistisairaus } & $\mathrm{Ei}$ & 173 & $1,03(1,0-1,2)$ & $0,002^{2}$ \\
\hline & & Kyllä & 140 & $1,10(1,0-1,3)$ & \\
\hline & \multirow[t]{2}{*}{ Masennus } & $\mathrm{Ei}$ & 287 & $1,06(1,0-1,2)$ & $0,002^{2}$ \\
\hline & & Kyllä & 26 & $1,19(1,1-1,6)$ & \\
\hline & \multirow[t]{2}{*}{ Ei käytösoireita } & $\mathrm{Ei}$ & 221 & $1,13(1,0-1,4)$ & $<0,001^{2}$ \\
\hline & & Kyllä & 92 & $1,00(1,0-1,0)$ & \\
\hline & \multicolumn{5}{|l|}{ Hoitosuhde } \\
\hline & \multirow[t]{3}{*}{ Vaatimukset } & Erittäin tai melko usein & 29 & $1,23(1,0-1,6)$ & $<0,001^{1}$ \\
\hline & & Joskus tai harvoin & 150 & $1,13(1,0-1,4)$ & \\
\hline & & Ei koskaan & 134 & $1,09(1,0-1,1)$ & \\
\hline & \multirow[t]{3}{*}{ Taloustilanteen heikentyminen } & Melko tai erittäin paljon & 46 & $1,10(1,0-1,3)$ & $0,038^{1}$ \\
\hline & & Jonkin verran & 103 & $1,10(1,0-1,4)$ & \\
\hline & & Erittäin vähän tai vähän & 164 & $1,06(1,0-1,2)$ & \\
\hline \multirow[t]{9}{*}{ Fyysinen väkivalta } & Hoidettava & & & & \\
\hline & Masennus & $\mathrm{Ei}$ & 287 & $1,00(1,0-1,0)$ & $0,046^{2}$ \\
\hline & & Kyllä & 26 & $1,00(1,0-1,2)$ & \\
\hline & Ei käytösoireita & $\mathrm{Ei}$ & 221 & $1,00(1,0-1,2)$ & $<0,001^{2}$ \\
\hline & & Kyllä & 92 & $1,00(1,0-1,0)$ & \\
\hline & Hoitosuhde & & & & \\
\hline & Vaatimukset & Erittäin tai melko usein & 29 & $1,00(1,0-1,2)$ & $0,005^{1}$ \\
\hline & & Joskus tai harvoin & 150 & $1,00(1,0-1,0)$ & \\
\hline & & Ei koskaan & 134 & $1,00(1,0-1,0)$ & \\
\hline Henkinen väkivalta & Omaishoitaja & & & & \\
\hline & Terveydentila & Hyvä & 26 & $1,00(1,0-1,1)$ & $0,017^{1}$ \\
\hline & & Melko hyvä & 99 & $1,00(1,0-1,5)$ & \\
\hline & & Kohtalainen & 159 & $1,25(1,0-1,8)$ & \\
\hline & & Melko huono tai huono & 29 & $1,00(1,0-1,8)$ & \\
\hline & Asuminen hoidettavan kanssa & Sama talous & 267 & $1,25(1,0-1,5)$ & $0,005^{2}$ \\
\hline & & Eri Talous & 46 & $1,00(1,0-1,3)$ & \\
\hline & Hoidettava & & & & \\
\hline & Sukupuoli & Nainen & 125 & $1,00(1,0-1,3)$ & $0,001^{2}$ \\
\hline & & Mies & 188 & $1,25(1,0-1,8)$ & \\
\hline & Suhde omaishoitajaan & Puoliso tms. & 206 & $1,25(1,0-1,8)$ & $0,001^{1}$ \\
\hline & & Äiti, isä & 53 & $1,00(1,0-1,1)$ & \\
\hline & & Tytär, poika & 38 & $1,00(1,0-1,3)$ & \\
\hline & & Muu & 16 & $1,00(1,0-1,9)$ & \\
\hline & Muistisairaus & $\mathrm{Ei}$ & 173 & $1,00(1,0-1,5)$ & $0,001^{2}$ \\
\hline & & Kyllä & 140 & $1,25(1,0-1,8)$ & \\
\hline & Masennus & $\mathrm{Ei}$ & 287 & $1,00(1,0-1,5)$ & $0,044^{2}$ \\
\hline & & Kyllä & 26 & $1,25(1,0-2,5)$ & \\
\hline & Ei käytösoireita & $\mathrm{Ei}$ & 221 & $1,25(1,0-1,8)$ & $<0,001^{2}$ \\
\hline & & Kyllä & 92 & $1,00(1,0-1,0)$ & \\
\hline & Hoitosuhde & & & & \\
\hline & Vaatimukset & Erittäin tai melko usein & 29 & $1,25(1,0-2,3)$ & $<0,001^{1}$ \\
\hline & & Joskus tai harvoin & 150 & $1,25(1,0-1,8)$ & \\
\hline & & Ei koskaan & 134 & $1,00(1,0-1,3)$ & \\
\hline Taloudellinen hyväksikäyttö & Hoidettava & & & & \\
\hline & Skitsofrenia ${ }^{3}$ & $\mathrm{Ei}$ & 310 & $1,00(1,0-1,0)$ & $0,016^{2}$ \\
\hline & & Kyllä & 3 & $1,00(1,0-)$ & \\
\hline & Hoitosuhde & & & & \\
\hline & Hoitamisen useus $^{3}$ & Useita kertoja päivässä & 260 & $1,00(1,0-1,0)$ & $0,010^{1}$ \\
\hline & & 1-2 kertaa päivässä & 24 & $1,00(1,0-1,0)$ & \\
\hline & & Useita kertoja viikossa & 17 & $1,00(1,0-1,0)$ & \\
\hline & & Harvemmin & 12 & 1,00 (--------) & \\
\hline
\end{tabular}

(jatkuu) 


\begin{tabular}{|c|c|c|c|c|c|}
\hline Kaltoinkohtelun ulottuvuus & Taustamuuttuja & Muuttujan luokat & $\mathbf{n}$ & Md (Q1-Q3) & p-arvo \\
\hline Henkilökohtaisten oikeuksien & Omaishoitaja & & & & \\
\hline \multirow[t]{20}{*}{ loukkaaminen } & Asuminen hoidettavan kanssa & Sama talous & 267 & $1,00(1,0-1,4)$ & $0,006^{2}$ \\
\hline & & Eri talous & 46 & $1,00(1,0-1,0)$ & \\
\hline & Hoidettava & & & & \\
\hline & Suhde omaishoitajaan & Puoliso tms. & 206 & $1,00(1,0-1,4)$ & $0,007^{1}$ \\
\hline & & Äiti, isä & 53 & $1,00(1,0-1,1)$ & \\
\hline & & Tytär, poika & 38 & $1,00(1,0-1,1)$ & \\
\hline & & Muu & 16 & $1,00(1,0-1,1)$ & \\
\hline & Muistisairaus & $\mathrm{Ei}$ & 173 & $1,00(1,0-1,3)$ & $0,006^{2}$ \\
\hline & & Kyllä & 140 & $1,00(1,0-1,4)$ & \\
\hline & Masennus & $\mathrm{Ei}$ & 287 & $1,00(1,0-1,3)$ & $0,025^{2}$ \\
\hline & & Kyllä & 26 & $1,21(1,0-1,6)$ & \\
\hline & Ei käytösoireita & $\mathrm{Ei}$ & 221 & $1,00(1,0-1,4)$ & $<0,001^{2}$ \\
\hline & & Kyllä & 92 & $1,00(1,0-1,0)$ & \\
\hline & Hoitosuhde & & & & \\
\hline & Vaatimukset & Erittäin tai melko usein & 29 & $1,14(1,0-1,6)$ & $0,001^{1}$ \\
\hline & & Joskus tai harvoin & 150 & $1,00(1,0-1,4)$ & \\
\hline & & Ei koskaan & 134 & $1,00(1,0-1,1)$ & \\
\hline & Taloustilanteen heikentyminen & Melko tai erittäin paljon & 46 & $1,00(1,0-1,6)$ & $0,006^{1}$ \\
\hline & & Jonkin verran & 103 & $1,00(1,0-1,6)$ & \\
\hline & & Erittäin vähän tai vähän & 164 & $1,00(1,0-1,3)$ & \\
\hline \multirow[t]{16}{*}{ Seksuaalinen väkivalta } & Omaishoitaja & & & & \\
\hline & $\mathrm{Ikä}^{3}$ & $38-60$-vuotiaat & 42 & $1,00(1,0-1,0)$ & $0,031^{1}$ \\
\hline & & 61-69-vuotiaat & 87 & $1,00(1,0-1,0)$ & \\
\hline & & 70-79-vuotiaat & 131 & $1,00(1,0-1,0)$ & \\
\hline & & $\geq 80$-vuotiaat & 54 & $1,00(1,0-1,0)$ & \\
\hline & Asuminen hoidettavan kanssa ${ }^{1}$ & Sama talous & 268 & $1,00(1,0-1,0)$ & $0,030^{2}$ \\
\hline & & Eri talous & 46 & 1,00 (--------) & \\
\hline & Hoidettava & & & & \\
\hline & Sukupuoli $^{3}$ & Nainen & 126 & $1,00(1,0-1,0)$ & $0,001^{2}$ \\
\hline & & Mies & 188 & $1,00(1,0-1,0)$ & \\
\hline & Muistisairaus $^{3}$ & $\mathrm{Ei}$ & 173 & $1,00(1,0-1,0)$ & $0,005^{2}$ \\
\hline & & Kyllä & 141 & $1,00(1,0-1,0)$ & \\
\hline & Masennus & $\mathrm{Ei}$ & 288 & $1,00(1,0-1,0)$ & $0,001^{2}$ \\
\hline & & Kyllä & 26 & $1,00(1,0-1,6)$ & \\
\hline & Ei käytösoireita $^{3}$ & $\mathrm{Ei}$ & 222 & $1,00(1,0-1,0)$ & $0,031^{2}$ \\
\hline & & Kyllä & 92 & $1,00(1,0-1,0)$ & \\
\hline \multirow[t]{12}{*}{ Sosiaalinen kaltoinkohtelu } & Hoidettava & & & & \\
\hline & Muistisairaus & $\mathrm{Ei}$ & 173 & $1,00(1,0-1,0)$ & $0,009^{2}$ \\
\hline & & Kyllä & 140 & $1,00(1,0-1,3)$ & \\
\hline & Ei käytösoireita & $\mathrm{Ei}$ & 221 & $1,00(1,0-1,3)$ & $<0,001^{-}$ \\
\hline & & Kyllä & 92 & $1,00(1,0-1,0)$ & \\
\hline & Hoitosuhde & & & & \\
\hline & Vaatimukset & Erittäin tai melko usein & 29 & $1,25(1,0-1,8)$ & $<0,001$ \\
\hline & & Joskus tai harvoin & 150 & $1,00(1,0-1,3)$ & \\
\hline & & Ei koskaan & 134 & $1,00(1,0-1,0)$ & \\
\hline & Taloustilanteen heikentyminen & Melko tai erittäin paljon & 46 & $1,00(1,0-1,3)$ & $<0,001$ \\
\hline & & Jonkin verran & 103 & $1,00(1,0-1,3)$ & \\
\hline & & Erittäin vähän tai vähän & 164 & $1,00(1,0-1,0)$ & \\
\hline \multirow[t]{9}{*}{ Hengellinen kaltoinkohtelu } & Hoidettava & & & & \\
\hline & Parkinsonin tauti ${ }^{3}$ & $\mathrm{Ei}$ & 288 & $1,00(1,0-1,0)$ & $0,041^{2}$ \\
\hline & & Kyllä & 25 & $1,00(1,0-1,0)$ & \\
\hline & Ei käytösoireita $^{3}$ & $\mathrm{Ei}$ & 221 & $1,00(1,0-1,0)$ & $0,014^{2}$ \\
\hline & & Kyllä & 92 & $1,00(1,0-1,0)$ & \\
\hline & Hoitosuhde & & & & \\
\hline & Vaatimukset $^{3}$ & Erittäin tai melko usein & 29 & $1,00(1,0-1,0)$ & $0,003^{1}$ \\
\hline & & Joskus tai harvoin & 150 & $1,00(1,0-1,0)$ & \\
\hline & & Ei koskaan & 134 & $1,00(1,0-1,0)$ & \\
\hline
\end{tabular}

